Research Report No. 24/2013

\title{
The Public Fiduciary: Emerging Themes in Canadian Fiduciary Law for Pension Trustees
}

Edward J. Waitzer

Osgoode Hall Law School of York University, ewaitzer@osgoode.yorku.ca

Douglas Sarro

Follow this and additional works at: http://digitalcommons.osgoode.yorku.ca/clpe

\section{Recommended Citation}

Waitzer, Edward J. and Sarro, Douglas, "The Public Fiduciary: Emerging Themes in Canadian Fiduciary Law for Pension Trustees" (2013). Comparative Research in Law \& Political Economy. Research Paper No. 24/2013.

http://digitalcommons.osgoode.yorku.ca/clpe/271 


\section{OSGOODE}

OSGOODE HALL LAW SCHOOL YOR K U N I VERSITY

\section{OSGOODE HALL LAW SCHOOL}

Comparative Research in Law \& Political Economy

RESEARCH PAPER SERIES

Research Paper No. 24/2013

The Public Fiduciary: Emerging Themes in Canadian Fiduciary Law for Pension Trustees

Edward J. Waitzer and Douglas Sarro

Editors:

Peer Zumbansen (Osgoode Hall Law School, Toronto, Director Comparative Research in Law and Political Economy)

John W. Cioffi (University of California at Riverside)

Leeanne Footman (Osgoode Hall Law School, Toronto, Production Editor)

Comparative Research in Law \& Political Economy 


\title{
THE PUBLIC FIDUCIARY: \\ EMERGING THEMES IN CANADIAN FIDUCIARY \\ LAW FOR PENSION TRUSTEES
}

\author{
Edward J Waitzer* and Douglas Sarro**
}

As society increasingly faces governance challenges at all levels, there is a growing recognition of the need to take a longer term and more systemic view of fiduciary obligations. We begin this article with a summary discussion of how fiduciary duties have developed and been applied in the pension fund context. We then review the efforts of the Supreme Court of Canada to develop a broader conceptual framework for fiduciary duties and consider steps that might be taken to address and mitigate liability in respect of these duties in the context of pension fund administration. We conclude by considering the trajectory of the law and how it appears to be positioning fiduciaries with public responsibilities and, in doing so, could alter legal and governance precepts.

Au fur et à mesure que les défis auxquels est confrontée la société en matière de gouvernance croissent, et ce, à tous les niveaux, il paraît de plus en plus évident qu'il faut favoriser une perspective plus systémique et à plus long terme à l'égard des obligations fiduciaires. Les auteurs débutent cet article en faisant une brève analyse de l'évolution des obligations fiduciaires et de leur application dans le contexte des fonds de pension. Ils examinent ensuite les efforts qu'a su faire la Cour suprême du Canada en vue d'élargir le cadre théorique des obligations fiduciaires et d'établir une démarche à suivre afin de régler et de mitiger la question de leur responsabilité en ce qui a trait à ces obligations dans le cadre de l'administration des fonds de pension. Les auteurs concluent en examinant le parcours du droit et la leçon dont il semble imposer aux fiduciaires des responsabilités publiques, ce qui pourrait avoir comme effet de modifier les préceptes du droit et de la gouvernance.

\section{Introduction}

Fiduciary duty is a dynamic concept - one that has responded to changing contexts and world views but is firmly rooted in clear and enduring legal Elliott LLP.

Osgoode Hall Law School and Schulich School of Business; Partner, Stikeman

** Osgoode Hall Law School, JD 2013. The authors thank Keith Ambachtsheer, Jim Hawley, Steve Lydenberg, Ben Richardson, and two anonymous reviewers for providing helpful comments. 
principles. As society increasingly faces governance challenges at all levels, there is a growing recognition of the need to take a longer term and more systemic view of fiduciary obligations, notwithstanding strong incentives to the contrary. This need is particularly acute in the financial services sector where, even as there has been a dramatic growth in reliance upon financial intermediaries (such as pension funds, sovereign wealth funds and other institutional investors) and a growing recognition of the exposure of such intermediaries to systemic and extra-financial risks, competencies and incentives remain severely misaligned.

Technology and innovation have fueled increased complexity in financial flows and instruments. This has led to increased reliance on a longer and more conflicted chain of service providers and increased market volatility. ${ }^{1}$ A recent survey of European pension fund executives and asset managers concluded that "there is a widespread perception in the pension world that the investment industry is perverse in one crucial sense: its food chain operates in reverse, with service providers at the top and clients at the bottom. Agents fare better than principals." 2 Any system built on a mismatch between expectations and outcomes is inherently problematic.

In the pension sector, ${ }^{3}$ Canada is uniquely positioned to inform the evolution of fiduciary standards as a legal response to these concerns for a number of reasons. For one, it "punches above its weight" in respect of the framework for public pension fund management. Indeed, the "Canada model" of pension management and delivery - which is based on a recognition that size, costs, and governance matter ${ }^{4}-$ has gained international prominence for its effectiveness and efficiency. ${ }^{5}$ Canada is

1 See e.g. Henry TC Hu, “Too Complex to Depict? Innovation, 'Pure Information' and the SEC Disclosure Paradigm" (2012) 97 Tex L Rev 1601.

2 Amin Rajan, DB \& DC Plans: Strengthening Their Delivery (Tunbridge Wells, UK: CREATE-Research, 2008).

3 While much of the research in this area has focused on pension funds to the exclusion of other financial institutions, the key issues are generic and interrelated; see e.g. John Kay, The Kay Review of UK Equity Markets and Long-Term Decision Making: Final Report, online: (2012) Kay Review <www.bis.gov.uk/assets/biscore/business-law /docs/k/12-917-kay-review-of-equity-markets-final-report $>$. Kay recommends that fiduciary standards be applied to "all relationships in the investment chain which involve discretion over the investment of others or advice on investment decisions" and that these obligations "should not be capable of being contractually overridden;" see ibid at 13 .

4 See e.g. Keith Ambachtsheer, "Pension Fund Governance: Five Top Challenges ... And How to Address Them" The Ambachtsheer Letter 310 (January 2012) [on file with authors].

5 "Canada's pension funds - Maple Revolutionaries" The Economist 402:8774 (3 May 2012) 84, online: Economist <www.economist.com/node/21548970/print>. 
also unique in that its courts (the Supreme Court of Canada in particular) have focused over an extended period of time (and in a variety of contexts) on developing a coherent view of the nature of fiduciary relationships and the consequences thereof. In doing so, they have extended the scope for fiduciary duties and consequential remedies.

We begin this article with a summary discussion of fiduciary duties as they have developed and been applied in the pension fund context. We then review the efforts of the Supreme Court of Canada to develop a broader conceptual framework for fiduciary duties. Having outlined theories of liability that have arisen from this effort, we consider, in the context of pension fund administration, steps that might be taken to address and mitigate liability in respect of these duties.

We conclude by considering the trajectory of the law - why fiduciaries are increasingly required to look beyond the immediate imperatives of the market (at least as they seem at the time) towards longer-term, systemic concerns, such as intergenerational equity and sustainable development. This trajectory appears to be positioning fiduciaries with public responsibilities and, in doing so, could alter legal and governance precepts.

\section{The Evolving Obligations of Pension Fund Trustees}

Pension trustees are subject to fiduciary obligations under common law and pension regulation. These include duties of care, ${ }^{6}$ loyalty to the interests of beneficiaries, and obedience to the purposes of the fund. ${ }^{7}$ Unlike corporate law (where directors' duties are to act in the best interests of the corporation as a whole), trustees' duties are to individual beneficiaries.

Fiduciary law is not static, nor, in the context of trusts, is it tied to a particular investment theory. ${ }^{8}$ It has proven to be a remarkably flexible set

6 We recognize that there is a distinction between the duties owed by fiduciaries and the duties owed by trustees, who are a species of fiduciary. We do, however, take the position that the duty of care, far from being a duty unique to trust law, pervades most of fiduciary law; see infra notes 78-83 and accompanying discussion.

7 Rob Atkinson, "Obedience as the Foundation of Fiduciary Duty" (2008) 34 J Corp L 43 .

8 See e.g. Martin Wilder and Paul H Curnow, Superannuation Trustees and Climate Change Report (Sydney: Baker \& McKenzie International, 2012), online: $<$ http://www.bakermckenzie.com/BKClimateChangeSuperannuationTrusteesOct12/>. In discussing changing expectations regarding long-term sustainability and the way in which investments should be made, the report observes at 26 that "trustees should adapt the way they apply the law to these changing circumstances and a defence that it has always been done this way or structurally from an industry perspective that is not possible is not acceptable." 
of principles, subject to varying interpretations over time. When explaining the rejection of prior interpretations of trustees' fiduciary obligations (which treated investment in equities as imprudent), the Restatement (Third) of Trusts observed:

Trust law should reflect and accommodate current knowledge and concepts. It should avoid repeating the mistake of freezing its rules against future learning and developments. ${ }^{9}$

Following the collapse of the South Sea Bubble ${ }^{10}$ in 1720, English courts of equity required trustees to restrict their investments to government obligations and mortgages. This was the genesis of the legal list approach, which restricted trustees to a prescribed list of investments. ${ }^{11}$ In Harvard College $v$ Amory, the Supreme Judicial Court of Massachusetts took a different approach, instructing trustees "to observe how men of prudence, discretion and intelligence manage their own affairs." 12 The flexibility of this objective behavioural standard was quickly circumscribed. In King $v$ Talbot, ${ }^{13}$ the New York Court of Appeals limited trustees to investments in government bonds and mortgages. State legislatures subsequently enacted legislation to the same effect. ${ }^{14}$ As recently as the 1970 s, stock investments were widely viewed as imprudent for trust fiduciaries. ${ }^{15}$

Over time, the market environment made this restrictive approach impractical. Trustees needed to hedge against inflation and the superior performance of equities (and foreign securities) militated in favour of diversification. So, too, did growing acceptance of modern portfolio theory, which suggested a portfolio-level approach to investment rather than an approach based on discrete consideration of particular investments. As a result, the legal paradigm shifted from restricted trustee powers to broad managerial discretion within the bounds of overarching fiduciary

$9 \quad$ See Restatement (Third) of Trusts: Prudent Investor Rule §227 (1992).

10 See John Carswell, The South Sea Bubble, rev ed (London: Alan Sutton Publishing Ltd, 1993). His comment that "[t]he maxim that credit was not wealth unless it rested on a wealth-producing asset had been ignored" could just as easily be said about today's financial crisis; see ibid at 241.

11 George Keeton, Modern Developments in the Law of Trusts (Belfast: Northern Ireland Legal Quarterly, 1971) at 46-62.

12 Harvard College v Amory, 9 Pick (26 Mass) 446 (1830).

1340 NY 76 (1869).

14 See W Brantley Phillips Jr, "Chasing Down the Devil: Standards of Prudent Investment Under the Restatement (Third) of Trusts" (1997) 54 Wash \& Lee L Rev 335 at 341 .

15 See Restatement (Second) of Trusts $\$ 227$, Comment (f) (1959). 
obligations. ${ }^{16}$ With the re-introduction of the "prudence standard" came the repeal of rules prohibiting the delegation of investment responsibilities, recognizing the growing complexity of managing financial assets and the need for trustees to rely on professionals. ${ }^{17}$

The prudent person standard was refined in the 1990s by recognizing that prudence should be measured on an overall portfolio basis. ${ }^{18}$ An incidental consequence was to shift pension fiduciaries' focus to portfoliolevel returns (based on the assumption that such a focus coincides with the interests of plan beneficiaries). This shift was reflected in modifications to the interpretation of the Employment Retirement Income Security Act of 1974 (ERISA) ${ }^{19}$ issued by the US Department of Labor. In discussing economically targeted investments, a 1994 Interpretive Bulletin stated that:

The Department has construed the requirements that a fiduciary act solely in the interest of, and for the exclusive purpose of providing benefits to, participants and beneficiaries as prohibiting a fiduciary from subordinating the interests of participants and beneficiaries in their retirement income to unrelated objectives. ${ }^{20}$

In contrast, this language was revised in 2008 to assert that:

Fiduciaries may never subordinate the economic interests of the plan to unrelated objectives, and may not select investments on the basis of any factor outside the economic interest of the plan except in very limited circumstances .... 21

Modern portfolio theory, in addition to prescribing a portfolio-level approach to investment, holds that price is the best guide to value, on the assumption that markets efficiently incorporate all available information about value (the efficient market hypothesis). Events of the last decade have challenged the narrow application of the efficient market hypothesis (and, as a result, the use of modern portfolio theory) as the basis for prudent investment and risk management practices, along with the legal

16 See e.g. Employee Retirement Income Security Act of 1974, 29 USC § 18.1104 (1974).

17 See e.g. Restatement (Second) of Trusts $§ 171$ (1959).

18 See e.g. Uniform Prudent Investor Act $\S \S 2$ (b), (f) (1994); Pensions Act 1995 (UK), 1995, c 26, ss 33(1), 35, 36(2). These standards also recognize a higher standard of care when a trustee is an investment professional

1929 USC $§ 1001$, et seq.

20 Interpretive bulletin relating to the fiduciary standard under ERISA in considering economically targeted investments, 29 CFR § 2509.94-1 (2000) [emphasis added].

21 US Department of Labor, Advisory Opinion 2007-07A (21 December 2007) and Advisory Opinion 2008-05A (27 June 2008) [emphasis added]. 
framework that recommends pension fiduciaries adhere to this theory. For example, it is now broadly accepted that most funds' returns come from general exposure to the market (beta) rather than seeking market benchmark out-performance strategies (alpha). ${ }^{22}$ This makes systemic market factors more critical to fiduciary responsibility.

There is also a growing recognition that "investment choice, like other life choices, is being re-tuned to a shorter wave-length," leading to irrational investment decisions - particularly with respect to projects of longer duration, which often yield the highest private (and social) returns. ${ }^{23}$ Even before the 2008 financial crisis, a joint study by two leading investment and business organizations found:

The obsession with short-term results by investors, asset management firms, and corporate managers collectively leads to the unintended consequences of destroying long-term value, decreasing market efficiency, reducing investment returns and impeding efforts to strengthen corporate governance. ${ }^{24}$

Pension fiduciaries are increasingly expected to consider questions of future value, rather than simply considering market price. Aside from the hazards of market volatility, they are expected "to assess the impact of their investment decisions on others, including generations to come," with all the uncertainties so entailed. ${ }^{25}$ There is a growing recognition that risk management for pension funds extends well beyond that which is captured by market benchmarks, requiring consideration of market integrity, systemic risks, governance risks, advisor risks and the like. ${ }^{26}$

22 Roger Ibbotson, "The Importance of Asset Allocation" (2010) 66 Financial Analysts J 18. While this concept is widely embraced by academics and market professionals, there remains a significant gap in practice. We suspect that many pension trustees would be hard pressed to explain the difference between alpha and beta in this context and that most continue to assess their managers in relation to benchmarks.

23 Andrew Haldane and Richard Davies, "The Short Long" (Paper presented to the 29th Société Universitaire Européene de Recherches Finanacières Colloquium, Brussels, May 2011), online: Bank of England <http://www.bankofengland.co.uk /publications/Documents/speeches/2011/speech495.pdf $>$.

24 CFA Centre for Financial Market Integrity and Business Roundtable, Institute for Corporate Ethics, "Breaking the Short-Term Cycle" (2006) 2006 CFA Institute. See also CFA Institute, "Visionary Board Leadership - Stewardship for the Long Term" (2012) 2012 CFA Institute.

25 Steve Lydenberg, "Reason, Rationality and Fiduciary Duty" J Bus Ethics (forthcoming in 2013) at 11, online: Springer Link $<$ http://link.springer.com/article/10 .1007\%2Fs10551-013-1632-3.>.

26 Metropolitan Life Insurance Company, "MetLife U.S. Pension Risk Behavior Index" (February 2012) online: Metropolitan Life Insurance Company <http://www. 
The manner in which undue focus on the duty of care (discussed below) as a liability mitigation strategy has created market volatility and undermined sustainable wealth creation has been documented elsewhere. ${ }^{27}$ In brief, the obsession with not underperforming the market has been driven, in part, by this duty (one can't be faulted for "buying the market," and cutting costs to help portfolio performance). While frequently characterized as long-term investing, this has been more accurately described as "perpetual investors making short-term investments forever." 28 It can lead to herding behavior and a short-term bias that amplifies the volatility created by speculators and high frequency traders, who are left to set market prices.

To the extent that current governance frameworks fail to facilitate a smooth transition in the pricing of systemic risk and other externalities, there are likely to be inflection points that trigger rapid re-pricing, with severe consequences for various types of assets (for example, when a realistic price is placed on carbon emissions). To take some recent examples, what rationale could there be for investing in gun (or tobacco) manufacturers other than a belief that society will not act to address the costs such enterprises impose on others? Pension trustees should be considering ways to mitigate consequential risks. ${ }^{29}$

Our thesis is that a renewed focus on the duty of loyalty (including responsibility for the oversight of supply-chain conflicts of interest, precautionary risk management, inter-generational impartiality and the incorporation of sustainability factors into investment management processes) would facilitate addressing these concerns.

\section{Mapping Fiduciary Duties: The Supreme Court of Canada's Heroic Quest}

To determine the relevance of the duty of loyalty, it is first necessary to examine the principles and purposes that have motivated its development, together with the broader development of fiduciary law. Common law courts have tended to sidestep this approach; relying on the assumption

metlife.com/assets/institutional/services/cbf/retirement/MetLife-2012-Pension-Risk -Behavior-Index-exp0213.pdf $>$.

27 See e.g. James P Hawley, Keith L Johnson and Edward J Waitzer, "Reclaiming Fiduciary Duty Balance" (2011) 2 Rotman Int'l J of Pension Mgmt 4.

28 Comment by Simon Zadek in his presentation at the International Corporate Governance Network Annual Conference (Rio di Janeiro, Brazil, July 2004), quoted in Simon Zadek, Mira Merme and Richard Samans, Mainstreaming Responsible Investment (Geneva: World Economic Forum, 2005) at 19.

29 Wilder and Curnow, supra note 8 at 8. 
(explicit or implied) that no principled basis for fiduciary law exists, they have adopted a category-based approach, under which relationships are recognized as fiduciary if they fall within, or sufficiently resemble historically recognized categories of fiduciary relationships. ${ }^{30}$ The Supreme Court of Canada has been an exception, showing unusual ambition in a protracted and deliberate effort to develop a broad conceptual framework for fiduciary duties. ${ }^{31}$

The Court's singular focus and unique perspective on fiduciary duties can be traced to its need to address Crown liability to Aboriginal peoples. In Guerin $v$ The Queen, ${ }^{32}$ the Court recognized a new class of fiduciary relationship between the Crown and Aboriginal peoples, under which the Crown could be liable as a fiduciary for encroachments on Aboriginal rights. In so doing, the Court rejected a category-based approach to fiduciary law, stating that "[i]t is the nature of the relationship, not the specific category of actor involved that gives rise to the fiduciary duty." 33 The Court went on to state that a relationship is fiduciary in nature where

30 Guerin v The Queen, [1984] 2 SCR 335 at 384 [Guerin] (listing trustees, solicitors, corporate directors, and partners as the four historically-recognized categories of fiduciary). See also Paul Miller, "A Theory of Fiduciary Liability" (2011) 56 McGill LJ 235 at 237 ("the law has evolved absent a general theory of liability"); James Edelman, "When do Fiduciary Duties Arise?" (2010) 126 LQ Rev 302 at 305 ("[a]midst this confusion and conflict [over the principles behind fiduciary duties], most commentators and judges are in agreement on one matter: the quest to define fiduciary relationships 'continues without evident sign of success"').

31 Though in the past, other common law courts have shown little interest in following Canada's approach, recent scholarship suggests that the gap between the approach taken in Canada and that taken in other jurisdictions is narrowing. Compare Breen v Williams (1996), 186 CLR 71 at para 15 (HCA) [Breen], per Brennan CJ ("the notion of fiduciary duty in Canada does not accord with the notion in the United Kingdom. Nor, in my opinion, does the Canadian notion accord with the law of fiduciary duty as understood in this country" (citations omitted)); Leonard I Rotman, "Fiduciary Law's 'Holy Grail': Reconciling Theory and Practice in Fiduciary Jurisprudence" (2011) 91 BU L Rev 921 at 950-52, 961-69 (comparing Canadian and American fiduciary jurisprudence, and concluding that similar considerations drive the development of fiduciary law in both countries).

32 Guerin, supra note 30 at 384.

33 Ibid. Though it has been argued that Guerin and other cases addressing fiduciary duties owed to Aboriginals may be separated from the general jurisprudence on fiduciary duties, the Supreme Court's frequent invocations of Guerin in cases involving other fiduciary relationships suggests that Guerin should be read as being integrated with the rest of the jurisprudence. See Robert Flannigan, "The Boundaries of Fiduciary Accountability" (2004) Can Bar Rev 35 at 67 (arguing that Guerin can be, or can already be considered, "detached" from the general jurisprudence); Alberta v Elder Advocates of Alberta Society, 2011 SCC 24, [2011] 2 SCR 261 at para 29 [Elder Advocates] (stating that Guerin establishes "foundational principles" for fiduciary law generally). 
one party (the fiduciary) has discretionary power over the interests of another (the beneficiary), and is obligated to use that power to serve the best interests of the other party. ${ }^{34}$ Fiduciary law aims to ensure that fiduciaries act in accordance with this obligation. ${ }^{35}$

In Hodgkinson $v$ Simms, ${ }^{36}$ the Court offered two related justifications for regulating the use of fiduciary power. First, fiduciary law compensates for beneficiaries' inherent vulnerability to abuse of power by fiduciaries. Because of the often highly specialized nature of fiduciary services, beneficiaries cannot meaningfully monitor the fiduciary's work and must trust the fiduciary to exercise care and look after their best interests. ${ }^{37}$ Such a relationship, the Court noted, cannot be "characterized by a dynamic of mutual autonomy," and for this reason, "the marketplace cannot always set the rules." 38 Instead, fiduciary law imposes a higher standard, rooted in norms of loyalty and good faith, to protect clients' interests. ${ }^{39}$

In protecting the interests of individual clients, the Court added, fiduciary law also seeks to protect the interests of the public as a whole. ${ }^{40}$ The Court noted that fiduciary services, which range from medicine, to lawyering, to financial advice, are vital to our economy and society at large. But individuals will not trust fiduciaries with their health or property, or to provide other specialized advice, unless they have reason to be confident that fiduciaries will not abuse this trust. ${ }^{41}$

This provides the second and principal justification for fiduciary law: to bolster public confidence in fiduciary services, and thus secure the

34 Guerin, ibid. See also Galambos v Perez, 2009 SCC 48, [2009] 3 SCR 247 at paras 70, 76 [Galambos].

35 Galambos, ibid at para 67.

36 [1994] 3 SCR 377 [Hodgkinson].

37 Ibid at $420-22$.

38 Ibid at 422.

39 Ibid.

40 Ibid.

41 Ibid. Beneficiaries' attitude towards fiduciaries can be expressed as "trust but verify." Though some have argued that the idea that beneficiaries should verify fiduciaries' loyalty is inimical to the idea of trust, some authors have managed to resolve this contradiction. See Richard Holton, "Fiduciary Relations and the Nature of Trust" (2011) 91 BU L Rev 991 at 992 ("In general, to trust is not to believe in performance; it is to act as if one believed. But the action-as-if can be partial. Indeed, it is almost bound to be partial. ... In particular, whilst trusting, it may be rational to verify that one will not be let down. Thus, the action-as-if only extends so far"); Tamar Frankel, Fiduciary Law (New York: Oxford University Press, 2011) at xvi [Frankel, Fiduciary Law] ("The Russian proverb 'Trust but verify' is self-contradictory but true. People compare the cost of trusting and relying on others with the cost of verification"). 
economic and social welfare these services promise, by "reinforc[ing] the integrity of [the] social institutions and enterprises" though which fiduciaries provide their services. ${ }^{42}$

The Court's definition of the nature of the fiduciary relationship, and its justifications for the imposition of fiduciary duties, draws from the work of scholars from Canada and abroad. ${ }^{43}$ For instance, in defining the social purpose of fiduciary duties, the Court relied heavily on scholarship chronicling the rise of the "fiduciary society." 44 The central aspect of a fiduciary society is a high degree of specialization in the professions. ${ }^{45}$ Specialization is intended to spur knowledge creation and generate wealth for individuals and society as a whole. ${ }^{46}$

Specialization also makes us more interdependent - it requires us to trust and rely on the expertise and services of strangers. ${ }^{47}$ Lawyers rely on

42 Hodgkinson, ibid.

43 The concept of a fiduciary relationship as one involving the exercise of discretionary power, coupled with an obligation to use that power in the interests of the fiduciary, as well as the idea that fiduciary law operates to protect vulnerable beneficiaries from the abuse of fiduciary power, had already been well-developed prior to Guerin, and continues to reflect current scholarly views. See e.g. Ernest J Weinrib, "The Fiduciary Obligation" (1976) 25 UTLJ 1 at 4-5 ("the fiduciary must have scope for the exercise of discretion, and, second, this discretion must be capable of affecting the legal position of the principal ... [t]he wide leeway afforded to the fiduciary to affect the legal position of the principal in effect puts the latter at the mercy of the former, and necessitates the existence of a legal device which will induce the fiduciary to use his power beneficently"); PD Finn, The Fiduciary Obligation (Sydney: The Law Book Co, 1977) at 3 (defining fiduciaries as "a class of persons who, having been entrusted with powers for another's benefit, are under a general equitable obligation when dealing with those powers, to act honestly in what they consider to be that other's interests"). See also Frankel, Fiduciary Law, supra note 41 at 7-8; Deborah A DeMott, "Beyond Metaphor: An Analysis of Fiduciary Obligation" (1988) 37 Duke LJ 879 at 915; Deborah A DeMott, "Breach of Fiduciary Duty: On Justifiable Expectations of Loyalty and Their Consequences" (2006) 48 Ariz L Rev 925 at 945 [DeMott, "Breach of Fiduciary Duty"]; D Gordon Smith, "The Critical Resource Theory of Fiduciary Duty" (2002) 55 Vanderbilt Law Review 1399, 1402; Robert H Sitkoff, "The Economic Structure of Fiduciary Law" (2011) 91 BU L Rev 1039 at 1049.

44 Frankel, "Fiduciary Law" (1983) 71 Ca L Rev 795 at 802.

45 Ibid at 803.

46 Ibid. See also Weinrib, supra note 43 at 11 ("'[a] sophisticated industrial and commercial society requires that its members be integrated rather than autonomously self-sufficient").

47 Frankel, Fiduciary Law, supra note 41 at 271; Tamar Frankel, "Fiduciary Law in the Twenty-First Century" (2011) 91 BU L Rev 1289 at 1292; James E Post, "Governance, Accountability, and Trust: A Comment on the Work of Tamar Frankel" (2011) BU L Rev 1165, 1173. 
doctors for medical care, who in turn rely on financial advisors to invest their savings, and so the cycle goes. The rise of the fiduciary society, in this sense, is a classic nonzero-sum game, where every player can benefit, but only so long as these players co-operate with one another. ${ }^{48}$ If fiduciaries breach their duties, and beneficiaries lose trust in fiduciary services and sever their relationships with fiduciaries, the game fails and everyone loses. The recent financial crisis demonstrates the scale of the costs of noncooperation, and how these costs are likely to continue to grow as financial flows and instruments become more complex. ${ }^{49}$

The Court's understanding that fiduciaries serve a public purpose, and its belief that fiduciary law should therefore respond to changing social needs, has led it to adopt a dynamic approach to determining (a) when fiduciary obligations arise and (b) the nature and scope of these obligations.

Though other common law jurisdictions have not explicitly adopted the Supreme Court's approach, it has been argued that some of these courts have been motivated by similar considerations. ${ }^{50}$ The Court's focus on the public interests served by fiduciaries also reflects approaches taken by civil law jurisdictions with respect to fiduciary-like duties. ${ }^{51}$

As such, the Court's reasoning, through an extended series of decisions, provides guidance as to the likely course of fiduciary law. Due to its focus on evolving public interests and needs, the Court's work is highly relevant to pension trustees, a class of fiduciary that will need to grapple with considerable social and institutional challenges in the coming years.

48 That fiduciary services tend to carry considerable social importance, and often require considerable training and expertise to provide, reinforces the need for cooperation. For more on nonzero-sum games and game theory in general, see Robert Axelrod, The Evolution of Co-operation, rev ed (New York: Basic Books, 2006); Anatol Rapoport, "Fights, Games, and Debates" (Ann Arbor: University of Michigan Press, 1960).

49 Post, supra note 47 at 1166-67; Joshua Getzler, “'As If.' Accountability and Counterfactual Trust" (2011) 91 BU L Rev 973 at 973 [Getzler, “"As If”'].

50 See Rotman, supra note 31 at 950-52, 961-69 (comparing Canadian and American fiduciary jurisprudence, and concluding that similar considerations drive the development of fiduciary law in both countries).

51 See e.g. German Corporate Governance Code, as amended on 15 May 2012 (highlighting the importance of "promot[ing] the trust of ... the general public in the management and supervision of listed German stock corporations," and citing directors' "obligation ... to ensure the continued existence of the enterprise and its sustainable creation of value in conformity with the principles of the social market economy" [emphasis added]). 


\section{A) When Fiduciary Obligations Arise}

The Court's test for determining whether fiduciary obligations arise flows from its definition of the nature of the fiduciary relationship. It has held that there are two necessary elements to a fiduciary relationship: (1) the beneficiary must be vulnerable to the discretionary power of the fiduciary, and (2) the fiduciary must be subject to an undertaking to exercise this discretionary power in the best interests of the beneficiary. ${ }^{52}$ The existence of these elements hinges on the "reasonable expectations" of the parties to the relationship - the extent to which an alleged beneficiary reasonably expects loyal conduct from the fiduciary, and the extent to which an alleged fiduciary could reasonably have expected to be bound by duties of loyalty and care. ${ }^{53}$

Fiduciary law's concern with the beneficiary's "inherent vulnerability to exploitative exercise of discretionary power by the fiduciary" 54 reflects equity's broad objective of "protect[ing] vulnerable parties in transactions with others," which it seeks to achieve through the combined effect of fiduciary law and the doctrines of undue influence and unconscionability. 55

In Frame $v$ Smith, ${ }^{56}$ Wilson $\mathrm{J}$ identified three hallmarks of a relationship of vulnerability:

(1) The fiduciary has scope for the exercise of some discretion or power.

(2) The fiduciary can unilaterally exercise that power or discretion so as to affect the beneficiary's legal or practical interests.

(3) The beneficiary is peculiarly vulnerable to or at the mercy of the fiduciary holding the discretion or power. 57

52 Elder Advocates, supra note 33 at paras 27-36.

53 Hodgkinson, supra note 36 at 412 (noting that fiduciary relationships turn on the "reasonable expectations of the parties" [emphasis added]); Galambos, supra note 34 at para 76 (noting that the reasonable expectations of one party alone will not in themselves give rise to a fiduciary relationship). This diverges from the approach advocated by some scholars, who argue that the reasonable expectations of the beneficiary should be sufficient to ground a fiduciary relationship; see e.g. DeMott, "Breach of Fiduciary Duty," supra note 43 at 936 ("The defining or determining criterion should be whether the plaintiff (or claimed beneficiary of a fiduciary duty) would be justified in expecting loyal conduct on the part of an actor and whether the actor's conduct contravened that expectation").

54 Miller, supra note 30 at 281.

55 Hodgkinson, supra note 36 at 405.

56 Frame v Smith, [1987] 2 SCR 99 [Frame].

57 Ibid at 136. Though this statement was made in dissent, it was later adopted by a majority of the Court; see Lac Minerals Ltd v International Corona Resources Ltd, [1989] 2 SCR 574 at 598-99 [Lac Minerals]. 
The extent to which a beneficiary is "peculiarly vulnerable to or at the mercy of" the fiduciary will depend on the extent to which the beneficiary reasonably expected that the fiduciary would act in his or her interests. Such a reasonable expectation leads beneficiaries to limit the extent to which they monitor the fiduciary's activities, or, where the fiduciary is an advisor, to accept a fiduciary's advice without closely scrutinizing it. The extent to which a beneficiary's expectation of loyal conduct is reasonable will depend on "factors such as trust, confidence, complexity of subject matter, and community or industry standards." 58

In Burke v Hudson's Bay Co, ${ }^{59}$ the Court concluded that a pension plan administrator and a pension's plan members and beneficiaries have a relationship with these characteristics, as a plan administrator has "wide discretion with respect to [a] pension plan, which it could exercise unilaterally and which could affect the interests of the [plan members] and to which exercise of discretion the [plan members] were vulnerable."60

Vulnerability alone, however, is not sufficient to establish a relationship as fiduciary in nature. The fiduciary must also be under an undertaking to use its discretionary power to serve the best interests of the beneficiary. ${ }^{61}$ The undertaking provides a basis on which the fiduciary could reasonably have expected to be bound to act with loyalty to a beneficiary's best interests and with reasonable care, diligence and skill.

To give rise to such a reasonable expectation, however, this undertaking generally must be made to a defined person or class of persons 62 and relate to a legal or substantial practical interest of the beneficiary. 63

58 Hodgkinson, supra note 36 at 412.

592010 SCC 34, [2010] 2 SCR 273.

$60 \quad$ Ibid at para 119.

61 Galambos, supra note 34 at para 69. See also Norberg $v$ Wynrib, [1992] 2 SCR 226 at 273 [Norberg].

62 Elder Advocates, supra note 33 at para 36. A charitable trust, which may be established to advance a social purpose rather than a defined group of beneficiaries, stands as an exception to this general rule. See Commissioners for Special Purposes of the Income Tax v Pemsel, [1891] AC 531 at 583; Vancouver Society of Immigrant and Visible Minority Women v MNR, [1999] 1 SCR 10 at paras 32-33.

63 Non-economic interests, including "fundamental human and personal interests," can meet this threshold; this sets Canada apart from other common law jurisdictions, such as Australia. See Norberg, supra note 61 at 276-77; Miller, supra note 30 at $275-76$. 
In the case of pension plan administrators, the undertaking generally arises by agreement, as set out in the plan documentation. ${ }^{64}$ An undertaking may also derive from a statute or a unilateral undertaking of the fiduciary. ${ }^{65}$ An undertaking may be express or implied. ${ }^{66}$ For example, an implicit undertaking arises when a person entrusts an advisor with information or seeks "advice in circumstances that confer a source of power," 67 so long as the advisor can be reasonably expected to counsel the "advised party as to how his interests will or might best be served." 68

The undertaking is central to a fiduciary obligation both because it establishes that the fiduciary could reasonably have expected that he or she would be bound to act with loyalty and care, and because it defines the scope of the fiduciary's obligations to act in this manner.

For instance, an employer that has also undertaken to act as a pension plan administrator has been held to wear "two hats." 69 When administering and investing the plan funds, the employer is using powers delegated to it as an administrator under the plan documentation, and thus owes fiduciary duties to plan members and beneficiaries. But when amending the plan, the employer is acting in its own capacity as employer and thus generally owes no fiduciary duties. ${ }^{70}$ However, a court will not allow a fiduciary to escape its fiduciary obligations through technicalities - for instance, where an employer/administrator uses its powers as an employer in a way that

64 Nolan v Kerry (Canada) Inc., 2009 SCC 39, [2009] 2 SCR 678 at para 85 [Nolan]. The Canada Pension Plan Investment Board's undertaking to invest funds in the best interests of contributors and beneficiaries is imposed by statute; see Canada Pension Plan Investment Board Act, SC 1997, c 40, s 5(b) [CPPIB Act].

65 Guerin, supra note 30 at 384.

66 Ibid at 384.

67 Galambos, supra note 34 at para 84.

68 Such a reasonable expectation will likely arise where and "the advisor would be expected both to be disinterested, save for his remuneration, and to be free of adverse responsibilities;" see PD Finn, "The Fiduciary Principle" in TG Youdan, ed, Equity, Fiduciaries and Trusts (Toronto: Carswell, 1989) 1 at 50-51, cited in Hodgkinson, supra note 34 .

69 Imperial Oil Ltd v Ontario (Superintendent of Pensions) (1995), 18 CCPB 198 at paras 30-33 [Imperial Oil]. The Crown has also been held to wear "multiple hats" when exercising fiduciary duties, unlike with respect to pension fund administrators, courts have held that the Crown's responsibilities to multiple constituencies give it discretion to abrogate its fiduciary duties unilaterally by legislation; see Authorson $v$ Canada (AG), 2003 SCC 39, [2003] 2 SCR 40 at para 15. In the case of fiduciary duties owed to Aboriginal people, which are constitutionally protected, the Crown is required to meet a justification test when infringing on its duty of loyalty; see $R v$ Sparrow, [1990] 1 SCR 1075; Delgamuukw v British Columbia, [1997] 3 SCR 1010.

70 Imperial Oil, ibid. The plan documentation sets out the contexts in which the administrator is acting as administrator and thus subject to the duty of loyalty. 
endangers the beneficiaries' existing interests in the plan, that employer will likely be held to a fiduciary standard. ${ }^{71}$

\section{B) Nature and Scope of the Duties}

Values of trust and loyalty, shaped by "reasonable expectations," form the basis of the broad fiduciary standards set by the Court. ${ }^{72}$ Hence, fiduciary duties are open-textured. ${ }^{73}$ It has been said that these standards are too vague to give meaningful guidance to fiduciaries. ${ }^{74}$ They do, however, help fiduciary law achieve its objective of instilling confidence in fiduciary services in two ways. First, open-textured standards can be more easily adapted to changing social needs. Second, by refusing to set bright line standards for fiduciary conduct, these standards ideally encourage fiduciaries to err on the side of caution, holding themselves to higher standards as a means of avoiding liability. ${ }^{75}$

The two primary duties flowing from the concept of the fiduciary relationship developed by the Supreme Court of Canada are the duties of care and loyalty. ${ }^{76}$ Below, we describe their nature, their scope, and their relationship to the concept of fiduciary duties developed by the Court.

71 Sun Indalex Finance LLC v United Steelworkers, 2013 SCC 6, [2013] SCJ No $6(\mathrm{QL})$ at paras 65-66, 269-71.

72 For discussion of the relationship between values of trust and loyalty and fiduciary law, see Margaret M Blair and Lynn A Stout, "Trust, Trustworthiness, and the Behavioural Foundation of Corporate Law” (2001) 149 U Pa L Rev 1735 at 1796.

73 Even those components of fiduciary duties that might be seen as relatively stable bright-line rules, such as the rule against conflicts, have been adapted over time to respond to changing social needs; see Finn, supra note 43 at 4 . A standard that is opentextured is not capable of precise definition. Instead, courts give them meaning by applying them to specific fact scenarios, drawing from the political and social culture in which these standards operate. Examples of open-textured standards may include "due process," "fairness," and "reasonable expectations;" see HLA Hart, The Concept of Law (Oxford: Clarendon Press, 1961) at 131-32.

74 See e.g. infra note 90 and accompanying discussion.

75 Lawrence E Mitchell, "The Death of Fiduciary Duties in Close Corporations" (1990) 138 U Pa L Rev 1675 at 1696 ("[t]he very ambiguity of the language conveys its moral content as the court's refusal to set lines is designed to discourage marginal conduct by making it difficult for a fiduciary to determine the point at which self-serving conduct will be prohibited, and thus to encourage conduct well within the borders.")

76 Hodgkinson, supra note 34 at 405; Blueberry River Indian Band v Canada (Department of Indian Affairs and Northern Development), [1995] 4 SCR 344 at para 38, per McLachlin J, concurring [Blueberry River]. 


\section{1) The Duty of Care}

As in the United States, ${ }^{77}$ the fiduciary's duty of care, skill and diligence has been held to be "at the heart of the fiduciary obligation" in Canada. ${ }^{78}$ The rest of the common law world, most notably England and Wales, appears to be gradually moving towards adopting the same position. ${ }^{79}$ That being said, a number of scholars and courts (at least historically) have argued that the duty of care is not a fiduciary duty, but a product of discrete areas of law governing specific categories of relationships, such as trust law and corporate law. ${ }^{80}$

This difference in view may be a product of different views of the purposes of fiduciary law. If one defines fiduciary law's purpose as being solely to deter self-dealing by fiduciaries, ${ }^{81}$ it is admittedly difficult to establish a logical connection between fiduciary obligations and a duty of care. But the Supreme Court of Canada has held that fiduciary law is intended to achieve the broader purpose of ensuring public confidence in social institutions. ${ }^{82}$ One means of achieving this purpose is to protect beneficiaries from the "careless, inept, or inattentive" exercise of the fiduciary's discretionary power over the beneficiary. ${ }^{83}$

It has also been argued that a fiduciary duty of care should not be recognized because it overlaps with the duties of care that apply in contract

77 See Part 2, above.

78 Blueberry River, supra note 76. But see KLBv British Columbia, 2003 SCC 51, [2003] 2 SCR 403 at para $49[K L B]$ (where the Supreme Court holds that parental fiduciary obligations do not include a duty of care). To date, the Supreme Court has not used $K L B$ as a precedent to further restrict the ambit of the fiduciary duty of care. For an account of other duties that have been recognized by Canadian courts, see Miller, supra note 26 at $257-58$.

79 See Futter $v$ Futter, [2011] EWCA Civ 197 at para 127 (recognizing that “trustees' duty to take relevant matters into account [in carrying out their responsibilities] is a fiduciary duty"); JD Heydon, "Are the Duties of Company Directors to Exercise Care and Skill Fiduciary?" in Simone Degeling and James Edelman, eds, Equity in Commercial Law (Sydney: Law Book Co, 2005) 185 (the author, a justice of the High Court of Australia, rejects existing Australian precedent and states that there is a fiduciary duty of care and skill).

80 See e.g. Flannigan, supra note 33; Breen, supra note 31; Bristol \& West Building Society $v$ Mothew, [1998] Ch 1[Mothew].

81 See e.g. Flannigan, ibid.

82 Hodgkinson, supra note 36 at 422. See also Rotman, supra note 31 at 950-52, 961-69 (arguing that the same justification for the imposition of fiduciary duties applies in the United States).

83 Miller, supra note 29 at 284. 
and tort law. ${ }^{84}$ Yet these classes of duties are distinguishable. The tort or contract duty of care imposes only a negative obligation to avoid acts that cause reasonably foreseeable harm to the beneficiary of the duty. ${ }^{85}$ The fiduciary duty of care, on the other hand, also imposes a positive obligation to exercise "diligence" in "determining whether and how to act upon [fiduciary] authority." 86 Furthermore, it requires the exercise of "skill," recognizing that fiduciary duties often arise because the fiduciary holds some special training or expertise. 87

The Court has summarized these positive and negative obligations in its requirement that a fiduciary exercise the same degree of care as "a person of ordinary prudence in managing his or her own affairs." 88 In the case of pension administrators, this standard of care has been elevated by statute, requiring the exercise of the same degree of care that "a person of ordinary prudence would exercise in dealing with the property of another person." 89

84 See WMC Gummow, "Compensation for Breach of Fiduciary Duty" in Youdan, supra note 68. See also Canson Enterprises Ltd v Boughton \& Co, [1991] 3 SCR 534 at 573 (rejecting this argument as being motivated by "a misguided sense of orderliness")

85 Cooper v Hobart, 2001 SCC 79, [2001] 3 SCR 537.

86 Miller, supra note 30 at 283. See also Rotman, supra note 31 at 959 (noting that fiduciary law "imposes strict duties consistent with the prescriptivism of equity, which stresses modes of behavior that are to be aspired to"); Julie Cassidy, "The Stolen Generation: Canadian and Australian Approaches to Fiduciary Duties" (2003) 34 Ottawa L Rev 175 at 207-209 ("a wealth of authority provides that equity does not merely impose proscriptive duties [requiring only that fiduciaries avoid certain activities], but also imposes positive duties on fiduciaries").

87 Miller, ibid. This is not to suggest that, in the context of pension administration, trustees with general intelligence and independent judgement, coupled with a commitment to the interests of beneficiaries, cannot contribute effectively.

88 Ermineskin Indian Band and Nation v Canada, 2009 SCC 9, [2009] 1 SCR 222 at para 131. See also Fales $v$ Canada Permanent Trust Co (1976), [1977] 2 SCR 302, 70 DLR (3d) 257 at 267 (which sets the standard as that of "a man of ordinary prudence in managing his own affairs"); Froese v Montreal Trust Co of Canada (1996) 137 DLR (4th) 725 (BC CA) at para 58 [Froese]; Adam v Adam (Estate of John Douglas Alexander Adam), 2003 MBQB 271 at para 22, (2003), 181 Man R (2d) 18; Estate of Therese Marie Sutherland, 2007 MBQB 70 at para 27 (2007), 215 Man R (2d) 38; Barabash Estate (Re), 1999 ABQB 656 at paras 13-14, [1999] AJ No 1012 (QL).

89 Pension Benefits Standards Act, 1985, RSC 1985, c 32 (2nd Supp), s 8(4) $[C P B S A]$ [emphasis added]. Provincial pension benefits statutes use similar language. This standard is presumed to be a higher one because a person is expected to be more prudent when managing another person's property than when managing his or her own; see Ari Kaplan, Pension Law (Toronto: Irwin Law, 2006) at 333. 
Critics of the "prudent person" standard include the Ontario Expert Commission on Pensions, which was led by Professor Harry Arthurs. The Arthurs Report called the standard "very vague," adding that it failed even to "lay down at least the main principles involving investment decisions." $" 90$

For instance, the prudent person standard does not make clear who bears the risk of liability when pension administrators delegate their responsibilities to consultants, advisors, and appraisers, a practice that is commonplace in today's investment environment. One of the foundations of fiduciary law is the idea that trustees will be deterred from abusing their powers when they know that they can be required to act "as if" they can be trusted by their beneficiaries. ${ }^{91}$ This powerful constraint on self-serving conduct is weakened where various arm's length professionals are retained to fulfill investment functions in place of trustees and the duties of such delegates are left unclear. The longer the supply chain becomes, the greater the risk that a conflict of interest will arise. ${ }^{92}$

Worse still, legal uncertainty creates perverse incentives for administrators to avoid liability by delegating responsibility, while the delegates in turn mitigate liability by contracting out of it, 93 by providing advice but not making final decisions, or by seeking indemnity. ${ }^{94}$ The result of these actions "can be a circular system in which no one takes responsibility and the interests of agents trump those of pension beneficiaries."95 While some jurisdictions have enacted legislation

90 Ontario, Expert Commission on Pensions, A Fine Balance: Safe Pensions, Affordable Plans, Fair Rules (Toronto: Queen's Printer for Ontario, 2008) at 85 [Arthurs Report].

91 See e.g. Joshua Getzler, “"As If,"” supra note 49 at 974. A trustee is required to act "as if" they can be trusted by surrendering any profits gained by abusing their discretionary power, in addition to compensating the beneficiary for any damages suffered. Thus, a fiduciary's scope of liability, and hence the power of fiduciary law as a deterrent, far exceeds the deterrents offered by tort and contract law, which focus solely on a plaintiff's actual losses rather than a defendant's gains.

$92 \mathrm{Hu}$, supra note 1 . See also Paul Wooley, "Investing for your own and the greater good," Alliance (June 2012) at 20, online: www.alliancemagazine.org.

93 See Ruth Sullivan, "UK debates fiduciary duty confusion" Financial Times (16 July 2012).

94 Hawley, Johnson and Waitzer, supra note 27 at 9.

95

Ibid. 
governing administrators' selection and monitoring of agents and subjecting agents to fiduciary duties, ${ }^{96}$ several have not. ${ }^{97}$

In response to this and other ambiguities arising from the prudent person standard, the Arthurs Report called for the replacement of the prudent person standard with a set of clear investment rules imposed by statute. ${ }^{98}$ A similar approach was adopted in the UK Companies Act 2006, requiring corporate directors to have regard for the long-term consequences of their decisions, including their likely effects on stakeholders, the broader community, and the environment. ${ }^{99}$ Reports have advocated similar guidance in the institutional investment context. ${ }^{100}$

It should be recalled that, historically, the duty of care was addressed, in part, through the application of quantitative and qualitative investment restrictions - imposing constraints on risk-taking by trustees by requiring investment in "safe" securities. At least one author has suggested the reinstatement of similar barriers "to recover the public dimension of trust institutions" - serving society's financial needs fairly and effectively. ${ }^{101}$

Even if these reforms are not implemented through statute, it is likely that they will influence the way in which courts interpret the prudent person standard. For instance, perhaps in recognition of the growing

96 See e.g. Pension Benefits Act, RSO 1990, c P.8, ss 22(5), (7)-(8) [OPBA]; Pension Benefits Standards Act, RSBC 1996, c 352, ss 8(7)-(8) [BCPBA]; Pension Benefits Act, RSNS 1989, c 34, ss 29(4)-(6) [NSPBA]; The Pension Benefits Act, CCSM, c P32, ss 28.1(6)-(8) [MPBA]; Pension Benefits Act, SNB 1987, c P-5.1, s 18. Québec, being a civil law jurisdiction, does not impose fiduciary duties per se on agents. It does, however, impose reporting and other obligations. See Supplemental Pension Plans Act, RSQ, c R-15.1, ss 154-154.4.

97 See e.g. CPBSA, supra note 89; Pension Benefits Act, 1992, SS 1992, c P6.001; Pension Benefits Act, 1997, SNL 1996, c P-4.01; Pension Fund Act, RSA 2000, c P-4. Prince Edward Island, Yukon, the Northwest Territories, and Nunavut do not have pension benefits legislation.

98 Arthurs Report, supra note 90 at 86.

99 Companies Act 2006 (UK), s 172.

100 See e.g. FairPensions, "Protecting Our Best Interests: Rediscovering Fiduciary Obligation" (March 2011) at 6, online: Fair Pensions <http://www.fairpensions .org.uk/sites/default/files/uploaded_files/fidduty/FPProtectingOurBestInterests.pdf $>$; Towers Watson, "We need a bigger boat: Sustainability in Investment" (2012) at 4, online: Towers Watson <http://www.towerswatson.com/assets/pdf/7818/TW-EU-2012 -26220-Sustainability-in-Investment.pdf $>$ (proposing a working definition of sustainable investing: long-term investing that is efficient, in that it provides the highest return per unit of risk, and inter-generationally sound, in that different generations get a similar sort of deal, allowing for risk).

101 Joshua Getzler, "Fiduciary Investment in the Shadow of Financial Crisis: Was Lord Eldon Right?” (2009) 3 J Equity 1 at 26. 
complexities of pension administration, and the emergence of a growing number of pension trustee education programs, ${ }^{102}$ this standard has already been interpreted to suggest that trustees of a pension plan should possess adequate training to carry out their responsibilities. ${ }^{103}$ It has also been held to require that they retain experts where necessary to help them make investment decisions, ${ }^{104}$ that administrators ensure "that the ... capital [of the plan] not be placed unduly at risk of loss," and "that the funds be invested in a way to generate a suitable rate of return." 105 The principle of diversification has been called "generally a good one to apply across a portfolio."106

The most important point to take away is that the prudent person standard, like all aspects of the fiduciary relationship, is dynamic, and likely to be elaborated and adapted as necessary to meet changing social and economic challenges and expectations.

\section{2) The Duty of Loyalty}

We have outlined how, with the ascent of the efficient market hypothesis and modern portfolio theory, the standard of the duty of care became interpreted as a convenient benchmark (and liability shield) for pension

102 See, for example, the Board Effectiveness Program developed by the International Centre for Pension Management at the Rotman School of Business (www.rijpm.com), the investment and governance courses offered by Shareholder Association for Research \& Education (www.share.ca) or the trustee programs developed by the Pensions and Capital Stewardship Project at Harvard Law School (www.law.harvard.edu/programs/lwp/LWPpensions_about.html).

103 That the prudent person standard refers to "ordinary prudence" rather than ordinary skill or knowledge reinforces the expectation that a fiduciary will undergo training to gain the knowledge and skill necessary to exercise his or her discretion prudently; see Canadian Association of Pension Supervisory Authorities (CAPSA), CAPSA Pension Plan Governance Guidelines (Toronto: CAPSA, 2003), "Principle 5: Knowledge and skills" at 7, online: CAPSA <http://www.capsa-acor.org/en/init /governance_guidelines/Guideline_Self-assess_Questionnaire.pdf $>$ [CAPSA Governance Guidelines]. To date, we are not aware of any training standard or requirement for pension trustees in Canada.

104 The statutes that apply to pension administrators confirm that administrators must use any relevant expertise they have or ought to have in exercising their authority. At common law, it has been held to be prudent for pension administrators, along with other fiduciaries, such as directors of corporations, to retain experts to aid in making decisions. See $R v$ Christophe, 2009 ONCJ 586 at para 23 [Christophe]; BCE Inc v 1976 Debentureholders, 2008 SCC 69, [2008] 3 SCR 560 at paras 152, 163 [BCE]. See also Kaplan, supra note 89 at 334.

105 Christophe, ibid at para 24. 
fiduciaries insofar as it encouraged them to adhere to common practices. 107 The hazards of this approach became evident during the financial crisis. The consequential increase in focus on short-term investing (coupled with the dramatic growth in pension assets) functioned like an "economic wavegeneration machine." 108 Herding behaviour created market volatility and undermined sustainable wealth creation. Likewise, excessive reliance on peer comparisons resulted in a shift towards relative performance metrics rather than a focus on risk-adjusted returns and the best interests of beneficiaries.

While the duty of care has been the focus of legal liability in recent years, there is no question as to the relative priority of the duty of loyalty:

When duties of loyalty and care collide, courts generally resolve the conflict in favour of the duty of loyalty representing minimum conduct to which the fiduciary must adhere. 109

The duty of loyalty is the central duty flowing from the fiduciary relationship. ${ }^{110}$ As noted, the social institutions that fiduciary law is intended to protect can function only if there is reason to trust that fiduciaries will use the powers granted to them to serve the best interests of their beneficiaries. Without this trust, individuals will be less likely to retain fiduciary services and they will lose the benefits associated with these services. As the Court has observed, this loss of trust will also harm the public at large. 111

The duty of loyalty requires that the fiduciary act in the best interests of the beneficiary. ${ }^{112}$ This general principle has provided the foundation for most of the concrete rules courts have traditionally imposed on fiduciaries. The duty of loyalty has been held to prohibit fiduciaries from (a) using their powers to their own advantage; ${ }^{113}$ (b) using their powers to

107 Russell Galer, Prudent Person Rule Standard for the Investment of Pension Fund Assets, (2002) 83 OECD Financial Market Trends.

108 Hawley, Johnson and Waitzer, supra note 27 at 7; Keith L Johnson and Frank Jan de Graaf, "Modernizing Pension Fund Legal Standards for the 21st Century" (2009) 2 Rotman Int'1 J of Pension Mgmt 44.

109 Arthur B Laby, "Resolving Conflicts of Duty in Fiduciary Relationships" (2004) 54 Am U L Rev 75.

$110 \mathrm{Ibid}$; Miller, supra note 30 at 270 (referring to the "cardinal fiduciary duty of loyalty").

111 Hodgkinson, supra note 36 at 422; Frankel, supra note 44 at 802

112 Galambos, supra note 34 at para 69.

113 Canadian Aero Services Ltd v O'Malley, [1974] SCR 592; Regal (Hastings) Ltd $v$ Gulliver, [1942] 1 All ER 378. This does not, however, prevent the fiduciary from securing "indirect or incidental" benefits for him or herself, or for third parties; see 
provide benefits for a third party; 114 (c) delegating their powers to a third party; 115 and (d) agreeing to act as a fiduciary for multiple persons who may have conflicting interests, without the informed consent of each person. ${ }^{116}$ It also has been held to require fiduciaries acting for multiple beneficiaries to (e) treat those beneficiaries impartially. ${ }^{117}$ This list is by no means exhaustive. ${ }^{118}$ Some of these rules, most notably (as noted above) the rule against delegation of powers, have been modified by statute and regulation. ${ }^{119}$

Given the open-textured nature of the duty of loyalty, courts may develop new rules to respond to changing social and economic needs. ${ }^{120}$ For example, courts have increasingly held that, in assessing the best interests of the beneficiary, a fiduciary must consider not only the beneficiary's narrow pecuniary interests, but the beneficiary's status as a responsible member of society. ${ }^{121}$ This means that it must comply with the law and generally avoid conduct that is unethical or otherwise does not reflect prevailing social norms. ${ }^{122}$ In summary, as its name implies, the duty of loyalty obliges "utmost loyalty to the beneficiary," both as an economic actor and as a responsible citizen. ${ }^{123}$

Lockheed Corp v Spink, 517 US 882 (1996) at 893-94, quoted in Nolan, supra note 64 at para 54.

114 Galambos, supra note 34 at para 31; Mothew, supra note 80.

115 A number of exceptions to this rule have been created by statute; courts have also taken a relatively relaxed approach to this rule at common law; see Finn, supra note 43 at 20 . As noted above, the state of the law as to the difference between the delegation of powers to a third party, which is generally not permissible, and the retention of advice, which is generally permissible, is less than clear; see supra notes 94-97 and accompanying discussion.

116 Mothew, supra note 80; Clark Boyce v Mouat, [1994] 1 AC 428.

117 See part 4 below.

118 For a more detailed account of these rules, see generally Frankel, Fiduciary Law, supra note 41; Leonard I Rotman, Fiduciary Law (Toronto: Carswell, 2006).

119 See Restatement (Second) of Trusts, supra note 17.

120 See Finn, supra note 43 at 4.

121 See $B C E$, supra note 104 at paras 43,81 (defining a director's duty of loyalty as being "to act in the best interests of the corporation viewed as a good corporate citizen" (emphasis added)). See also Joseph William Singer, "Corporate Responsibility in a Free and Democratic Society" (2008) 58 Case W Res L Rev 1; Andrew S Gold, "The New Concept of Loyalty in Corporate Law" (2009) 43 UC Davis L Rev 457; Ed Waitzer and Johnny Jaswal, "Peoples, BCE and the Good Corporate 'Citizen" (2009) 47 Osgoode Hall LJ 439 at 475-77.

122 Ibid.

123 Elder Advocates, supra note 33 at para 43; BCE, supra note 104 at paras 43, 81. 


\section{The Challenge of the Duty of Impartiality}

Acting in the best interests of a single beneficiary will in many cases be relatively straightforward. Assessing, and acting in, the best interests of multiple beneficiaries can be considerably more difficult, especially when the interests of different classes of beneficiaries conflict. In these cases, the duty of loyalty gives rise to a duty of even-handedness which requires a fiduciary to exercise its powers in an impartial manner. ${ }^{124}$ Given the range of interests of pension plan beneficiaries, meeting this standard is a challenge - one which the Court has only rarely addressed directly, and to which fiduciaries have largely avoided turning their minds.

Impartiality does not mandate equal outcomes, or even equal treatment. ${ }^{125}$ For example, in Anova Inc Employee Retirement Pension Plan (Administrator of) v Manufacturers Life Insurance Co, ${ }^{126}$ an employer was held to be permitted to provide early retirement inducements to a group of beneficiaries without making similar benefits available to other beneficiaries, because conferral of the benefit benefitted the company funding the plan, and thus benefitted the plan as a whole, and did not impair the administrator's ability to meet its obligations to other plan members. ${ }^{127}$ Likewise, in Neville $v$ Wynne, 128 the trustees, in the face of financial difficulties, decided to reduce benefits across the board and then further reduce benefits for active members. The British Columbia Court of Appeal upheld the trustees' decision, finding that the factors the trustees considered (including past increases for active members that outpaced those for retirees and widows) were reasonable and that "formal equality" between beneficiaries is not required. ${ }^{129}$

What the duty of impartiality does mandate is fair treatment, holding that "conduct in administering a trust cannot be influenced by a trustee's personal favouritism ... nor is it permissible for a trustee to ignore the interest of some beneficiaries merely as a result of oversight or neglect." 130

124 Restatement (Third) of Trusts: Prudent Investor Rule, § 78.

125 While the Court has yet to directly address this contention, several lower courts have accepted this aspect of the duty of impartiality. In doing so, they have relied on British authority. See infra note 130 and accompanying discussion.

126 (1994), 121 DLR (4th) 162 (Ont Ct (Gen Div)).

127 Ibid at para 58.

128 Neville $v$ Wynne, 2006 BCCA 460, 57 BCLR (4th) 199 [Neville].

129 Ibid at paras 3-5, 9.

130 Restatement (Third) of Trusts: Prudent Investor Rule, §78, Comment (b) (1992); see also Edge v Pensions Ombudsman, [1998] Ch 512, aff'd [1999] EWCA Civ 2013, 4 All ER 546 (CA); Kaplan, supra note 89 at 343; Neville, ibid at para 5; Dinney v Great-West Life Assurance Co et al, 2009 MBCA 29 at para 90, (2009), 236 Man R (2d) 299; Edell v Sitzer (2001), 55 OR (3d) 198 (SC) at para 173. 
The CFA Institute's Code of Conduct for Members of a Pension Scheme Governing Body states that a trustee must "consider the different types of beneficiaries relevant to each pension scheme" and "engage in a delicate balancing act of taking sufficient risk to generate long-term returns high enough to support real benefit increases for active participants who will become future beneficiaries while avoiding a level of risk that jeopardizes the safety of the payments to existing pensioners." 131 Not only must outcomes reflect due regard for different beneficiaries' interests, but the "process of administration itself," including communication with beneficiaries, must be impartial. ${ }^{132}$

The duty of impartiality assumes a level of proficiency (and, hence, implies a heightened duty of care) with respect to long-term value creation and risk mitigation. Peter Drucker recognized this challenge of intergenerational wealth generation in his epilogue to the 1996 edition of The Unseen Revolution. Drucker argued for a shift away from short-term thinking in favour of a focus on defining performance (and results) as "maximiz[ing] the wealth-producing capacity of the enterprise." $133 \mathrm{He}$ argued that institutional investors must play a vital role in driving this shift.

This means paying closer attention to reputational and sustainability concerns, concerns which strike at the heart of investee companies' ability to generate wealth in the long run, and which often have an intergenerational dimension. Consider, for example, the campaign for divestment from companies doing business in South Africa in the 1980s, which arose on college campuses and resulted in divestment by institutional investors, contributing to the elimination of apartheid. While the fossil-fuel industry (which includes a number of sovereign nations) may be a more challenging policy concern to address, the link for postsecondary students (and investors with long-term liabilities) is arguably more obvious. ${ }^{134}$

There are legitimate questions as to whether the challenge posed by the duty of impartiality can be met. Leaving aside issues regarding

131 Kurt Schacht and Jonathan Stokes, Code of Conduct for Members of a Pension Scheme Governing Body (Charlottesville, VA: CFA Institute, 2008).

132 Mark L Ascher, Austin Wakeman Scott and William Franklin Fratcher, Scott and Ascher on Trusts, 5th ed (New York: Aspen Law \& Business, 2006) § 17.15.

133 Peter F Drucker, The Pension Fund Revolution (New Brunswick, NJ: Transaction Publishers, 1996) at 218. This volume is a reprint of Peter F Drucker, The Unseen Revolution: How Pension Fund Socialism Came to America (New York: HarperCollins, 1976).

134 See Bill McKibben, “The Reckoning” Rolling Stone 1162 (2 August 2012) 52, online: Rolling Stone <www.rollingstone.com/politics/news/global-warmings-terrifying -new-math-20120719>. 
adequate tools and incentives to think and act with a view to the long run, there are concerns about the balancing of competing interests. DeMott claims that "fiduciary norms lose their bite when they are imposed on behalf of beneficiaries whose interests systematically conflict."135 Likewise, Marcoux claims that "[t]he nature of the fiduciary relationship is such that it is impossible for one to act as a fiduciary for multiple parties where the interests of those parties are (or are likely to be) in conflict."136 Hansmann and Kraakman assert that "imposing affirmative duties on management to protect simultaneously the interests of two or more groups is unworkable." 137

The question of whether a fiduciary can owe a duty to the interests of multiple parties whose interests may not coincide is not novel. One need only look to corporate law, where, as William T Allen suggested, "anyone trying to understand how our law deals with corporations must have in mind that they are the locus of many conflicting claims, and not all of those claims are wholly economic." 138 These conflicting claims became the focus of the Supreme Court's decision in BCE Inc $v 1976$ Debentureholders, which reviewed a decision by the board of BCE Inc that bondholders alleged was unfairly prejudicial to their interests. ${ }^{139}$ In reaffirming its reasons in Peoples Department Stores Inc (Trustee of) $v$ Wise, 140 the Court held that there is "no principle that one set of interests ... should prevail over another set of interests. Everything depends on the particular situation faced by the directors and whether ... they exercise business judgment in a responsible way."141 This means treating stakeholders "equitably and fairly," in accordance with their "reasonable

135 Deborah A DeMott, "Fiduciary Obligation under Intellectual Siege: Contemporary Challenges to the Duty to be Loyal" (1992) 30 Osgoode Hall LJ 471 at 497.

136 Alexei M Marcoux, "A Fiduciary Argument Against Stakeholder Theory" (2003) 13 Bus Ethics Q 1 at 4.

137 Henry Hansmann and Reiner Kraakman, "Reflections on the End of History for Corporate Law" in Abdul Rasheed and Toru Yoshikawa, eds, Convergence of Corporate Governance: Promise and Prospects (New York: Palgrave MacMillan, 2012) 32 at 37, online: SSRN <http://ssrn.com/abstract=2095419>. While these arguments (together with those cited in notes 135 and 136 above) focus on the challenge of corporate stakeholders, the issues are at least equally relevant amongst beneficiaries of a pension fund.

138 William T Allen, "Our Schizophrenic Conception of the Business Corporation"

(1992) 14 Cardozo L Rev 261 at 280.

139 BCE, supra note 104.

140 [2004] 3 SCR 461 [Peoples].

141 Ibid at para 84. 
expectations." 142 As was seen in Part 3, the meaning of "reasonable expectations" is highly malleable (indeed, somewhat tautological). In the corporate context, it has come to encompass "a broader and longer-term view" of the "best interests of the corporation," with due respect for social and environmental interests. ${ }^{143}$

The balance of this article will canvass legal theories which may assist in breathing life into this challenging duty of impartiality in the context of pension administration and suggest tools to assist in addressing it. In light of these theories, we argue that pension trustees will increasingly be obligated, as fiduciaries, to (a) demonstrate respect for social norms, (b) give beneficiaries a voice in decisions that affect their interests, and (c) think and act strategically and collectively. This effectively positions pension fund fiduciaries with public responsibilities to address long-term social concerns and imposes on them a duty to collaborate with each other in so doing.

While this outcome may sound somewhat radical, it comports with the nature of the duties of loyalty and care that form the foundation of fiduciary law. It also reflects fiduciary law's overriding concern with protecting public confidence in fiduciary services, which is crucial to preserving the dynamic of cooperation central to our fiduciary society. Furthermore, it reflects the personal and direct (i.e., to beneficiaries with social as well as economic interests) nature of pension trustees' fiduciary duties and the systemically important role pension funds play in our economy and our society more broadly.

\section{A) Respect for Social Norms and the Duty of Obedience}

Not unlike the duty of impartiality, the legal currency of the "duty of obedience" has waned over the years, but may be re-emerging. ${ }^{44}$ Rooted in the ultra vires doctrine, which required corporations to exercise their powers according to the governing statute and their corporate charter, the concept (if not the duty itself) has been revived in a series of recent US cases focusing on the obligation of corporate actors to have due regard for non-corporate norms. ${ }^{145}$

142 Ibid at para 64. See also Finn, supra note 43 at 6 (discussing the importance of "reasonable expectations" in defining the scope of fiduciary obligations).

143 Waitzer and Jaswal, supra note 121 at 496.

144 Atkinson, supra note 7.

145 For a more extensive discussion of the history of ultra vires and how it has been applied in American case law, see Kent Greenfield, The Failure of Corporate Law: Fundamental Flaws and Progressive Possibilities (Chicago: University of Chicago Press, 2007) at $115-175$. 
In re Caremark International Inc Derivative Litig146 addressed directors' failure to oversee corporate legal compliance systems, finding an obligation to ensure "corporate information and reporting systems" exist to provide "timely, accurate information sufficient to allow management and the board ... to reach informed judgments concerning the corporation's compliance with law and its business performance."147 Likewise, in Stone $v$ Ritter, ${ }^{148}$ the Court found that directors will have breached their duty of good faith if they "knew or should have known" of violations of law (in this case, suspicious bank transactions). Similar duties have been found in the not-for-profit sector. ${ }^{149}$

As Palmiter argues, the duty of obedience has become "the animating 'ghost"" behind such regimes as the "reasonable expectations" and "good faith" doctrines. ${ }^{150}$ The Supreme Court's decision in $B C E$ reflects a similar logic, expanding the duty of loyalty to require directors to act in the "best interests of the corporation viewed as a good corporate citizen" (emphasis added), which in turn are defined by reasonable expectations. ${ }^{151}$ This broader conception of the duty of loyalty, informed by the concept of a duty of obedience, comports with the idea of "loyalty" as "[a]cting honorably towards another." 152 It furthers the broader social purpose of fiduciary duties by requiring fiduciaries not to undertake unethical actions that would shake public confidence and trust in fiduciaries and the services they provide.

With this in mind, we consider how such a reinvigorated duty of loyalty may interact with pension trustees' other duties in a specific case: where trustees must determine the extent to which they will consider environmental, social, and governance (ESG) norms when making investment decisions.

Increasingly, the principle of responsible investment forms part of the fabric of social norms in which pension funds operate. ${ }^{153}$ The Outcome

146698 A (2d) 959 (Del Ct Ch 1996).

147 Ibid at 970.

148911 A (2d) 362 (Del Sup Ct 2006).

149 See Alan R Palmiter, "Duty of Obedience: The Forgotten Duty" (2010-2011) 55 NY L Sch L Rev 457.

150 Ibid at 478.

151 BCE, supra note 104 at paras 64, 66, 84; see also Peoples, supra note 140 at para 42 .

152 Gold, supra note 121 at 493.

153 See e.g. Laura O’Neill, "Social, Environmental, and Ethical Pension Fund Disclosure: International Precedents and Options for Canada" (Paper prepared for Environment Canada by Shareholder Association for Research \& Education (SHARE), March 2007) [unpublished, available from authors]. The Ontario Minister of Finance 
Document from the UN Conference on Sustainable Development in June 2012 (Rio + 20) acknowledged the importance of corporate sustainability reporting and encouraged companies to "consider integrating sustainability information into their reporting cycle." 154 In recent years each of France, ${ }^{155}$ Brazil, ${ }^{156}$ South Africa, ${ }^{157}$ and Denmark ${ }^{158}$ have adopted integrated sustainability reporting requirements. This reflects a growing awareness that systemic and ESG risks (and opportunities) with material consequences often are not captured or reflected in financial statements or other corporate reporting.

The European Commission has committed to "present a legislative proposal on the transparency of the social and environmental information provided by companies in all sectors." 159 At the recent Sustainable Stock Exchanges Global Dialogue, five of the major exchanges (NASDAQ, the Brazilian BM\&FBOVESPA, the Egyptian Exchange, the Istanbul Stock Exchange, and the Johannesburg Stock Exchange) committed to work with investors, companies and regulators to promote long-term sustainable investment and improved ESG disclosure and performance among their listed companies. ${ }^{160}$ The OMX Nordic Exchange has authority to

announced in his 2011 Budget Speech the government's plan to require pension plans to disclose whether their Statements of Investment Policies and Procedures address ESG factors; see Ontario, Ministry of Finance, 2011 Budget: Budget Papers (Toronto: Queen's Printer for Ontario, 2011) at 272-73, online: Ontario Ministry of Finance $<$ http://www.fin.gov.on.ca/en/budget/ontariobudgets/2011/papers_all.pdf $>$.

154 UN Commission on Sustainable Development, The Future We Want, UN Doc A/CONF.216/L.1 (2012) at para 47.

155 Loi $n^{\circ}$ 2010-788 du 12 juillet 2010 portant engagement national pour l'environnement, JO, 13 June 2010, 12905 [Grenelle II Act]. See also France, Ministry of Ecology, Sustainable Development and Energy, "Le Grenelle Environnement," online: Republique Française <http://www.legrenelle-environnement.fr $>$.

156 The BM\&FBOVESPA stock exchange is encouraging its listed companies to improve their reporting on ESG issues; see e.g. sources infra note 160.

157 The Johannesburg Stock Exchange has a "report or explain" requirement for integrated reporting. Johannesburg Stock Exchange, JSE Listing Requirements, s 8.63(a), online: Johannesburg Stock Exchange http://www.jse.co.za/How-To-List/Listingrequirements/JSE-listing-requirements.aspx (Service Issue 15).

158 Danish Financial Statements Act, Danish Act no 448 of 7 June 2001 (as amended), s 99a (requiring Denmark's largest public and private enterprises to report on their policies on corporate social responsibility).

159 European Commission, "Sustainable and responsible business $>$ CSR Reporting and Disclosure" (September 2011), online: European Commission $<$ http://ec .europa.eu/enterprise/policies/sustainable-business/corporate-social-responsibility /reporting-disclosure/index_en.htm>.

160 UNEP Finance Initiative \& Sustainable Stock Exchanges Initiative, Press Release, "Sustainable Stock Exchanges Initiative: Exchanges listing over 4,600 companies commit to promoting sustainability," online: (2012) UNEPFI <http://www. 
investigate (and presumably delist) companies that have committed a "serious or systematic violation of human rights or other ethical international norms." 161

The challenge for fiduciaries with long-term obligations (and risk exposures) is to integrate these factors into their investment management processes. A pension fund trustee's fiduciary duty of care requires it to ensure that pension capital is not "placed unduly at risk of loss." 162 Considering ESG factors when making investment/divestment decisions enables them to evaluate sources of risk that would otherwise be overlooked. Hence, for example, the Canada Pension Plan Investment Board (CPPIB), Canada's largest pension plan, adjusted to this reality by implementing a Policy on Responsible Investing that requires it to consider social and environmental factors when making investments. ${ }^{163}$ This policy also commits the CPPIB to engage with investee boards and managers to discuss concerns that arise with respect to these factors. ${ }^{164}$

But to what extent can trustees refuse to invest in certain companies, or certain sectors, on the basis of these factors? This question seems to place at odds the principle of responsible investment with the principle of diversification.

A 2005 report by the law firm Freshfields Bruckhaus Deringer LLP for the UN Environment Programme Finance Initiative concluded that fiduciaries could lawfully exclude investments that could "reasonably be assumed offensive to the average beneficiary" on the basis of "clear breaches of widely recognized norms, such as international conventions on human rights, labour conditions, tackling corruption and environmental protection." 165 Yet many major pension plans, including the CPPIB, have

unepfi.org/fileadmin/events/2012/Rio20/Press_release_Sustainable_Stock_Exchange .pdf $>$. Amanda White, "Exchanges support better disclosure" (13 July 2012), online: top1000funds.com <http://www.top1000funds.com/analysis/2012/07/13/exchanges -support-better-disclosure/>.

161 See online: <http://ir.nasdqomx.com/documentdisplay.cfm?DocumentID $=3898>$.

162 Christophe, supra note 104 at para 24.

163 Canada Pension Plan Investment Board (CPPIB), Policy on Responsible Investing (Toronto: Canada Pension Plan Investment Board, 2010), online: CPPIB $<$ http://www.cppib.ca/files/PDF/Responsible_Investing_Policy_August2010.pdf $>$.

164 Ibid, s 4.0 .

165 Freshfields Bruckhaus Deringer LLP, A Legal Framework for the Integration of Environmental, Social, and Governance Issues into Institutional Investment (London: Freshfields Bruckhaus Deringer LLP, 2005) at 96; but see Benjamin J Richardson, "Fiduciary Relationships for Socially Responsible Investing" (2011) Am Bus LJ 597 at 618-19 [Richardson, "Fiduciary Relationships"] (on the difficulty inherent in determining 
rejected the idea of screening investments based on ESG indicators, taking the view that their duty to act in the best interests of their beneficiaries obliges them to maintain a diversified portfolio. ${ }^{166}$

Two alternative approaches, which seek to reconcile the principles of diversification and responsible investment, are engagement and positive screening. ${ }^{167}$ Engagement includes direct consultation by plan representatives with firms within their portfolio, the exercise of proxy votes in support of shareholder proposals relating to ESG factors, and cooperation with other institutional investors to address collective ESG concerns. This follows logically from the obligation of pension fiduciaries to consider the welfare of beneficiaries. Profit seeking at any cost should not be conflated with fiduciary duty - a much higher standard.

Because engagement does not require the screening of investments, it is fully compatible with the principle of diversification (along with passive investment practices) and for this reason is widely used by institutional investors, including the CPPIB. ${ }^{168}$ In moving towards its target of having $30 \%$ of its portfolio exposed to real assets, British Columbia Investment Management Corporation (BCIMC) is seeking collaborative engagement opportunities with similar large institutional investors in that sector. ${ }^{169}$

Positive screening, also known as the best of sector approach, involves ranking competing firms in a given sector based on ESG criteria and investing in the best-performing firms in each sector. While this approach may not be strictly in accordance with modern portfolio theory, it does allow trustees to invest responsibly without excluding entire industries or

investors' views on the use of investment screens, and the somewhat softer position taken by the UNEP itself in its 2009 follow-up report).

166 CPPIB, supra note 163, s 2.0. The Ontario Teachers' Pension Plan takes the position that an investment screen could only be imposed via an amendment to its enabling statute. See Ontario Teachers' Pension Plan, "OTPP - Listening to Members" (September 2011), online: <http://www.otpp.com/wps/wcm/connect/otpp_en/Home /Responsible+Investing/Qs+and+As/>.

167 Finance and Investment Advisory Board, Review of the Application of Environmental, Social and Governance Principles to Territory Investment Practices (Australia, Capital Territory, 2007) at 32.

168 CPPIB, supra note 163, s 4.0.

169 Sam Riley, "Collaboration keep[s] deals on tap" (5 September 2012), online: top1000funds.com <http://www.top1000funds.com/news/2012/09/05/collaborationkeep-deals-on-tap/>. BCIMC also collaborates with other institutional investors on broader issues of responsible investment. BCIMC, From Complexity to Opportunity: Annual Report 2011-2012 (Vancouver: BCIMC, 2012) 39, online: BCIMC < http:// www.bcimc.com/publications/pdf/annualreport/bcIMC_AR_2012_web_All.pdf $>$. 
other sectors of the economy. ${ }^{170}$ Such an approach is reflected in the proliferation of market indices which reflect social and environmental inputs.

The Dutch pension manager PGGM has taken this approach a step further by creating a dedicated Responsible Equity Portfolio with a longterm investment horizon that integrates ESG factors with active ownership. The $€ 3$ billion portfolio targets 15 to 20 long-term holdings. Because of this level of concentration, risk tends to be stock-specific and thus requires close attention to ESG factors in respect of each stock. ${ }^{171}$

Whether pension fiduciaries choose to address ESG concerns through engagement, positive screening, or some combination of the two, they will need to justify their choice with reference to their duties of loyalty and care, which are owed to individual beneficiaries rather than to the pool of assets. ${ }^{172}$ As a consequence, pension fiduciaries must take into account the interests of those beneficiaries and seek to "do no harm" to them. ${ }^{173}$ In summary, investment policies that demonstrate active attention to ESG considerations, in addition to producing important social benefits, may be the least legally risky investment approach available to trustees.

\section{B) Giving Beneficiaries a Voice}

While our legal systems are infused with the notion of equity and fairness between contemporaries, we have yet to embrace the notion that justice should be facilitated between members of different generations. One exception has been in environmental law. For example, many of the provinces and the federal government have enacted sustainable development legislation, designed to improve environmental decisionmaking. The statutes define "sustainable development" as meeting present

170 Benjamin J Richardson, "Do the Fiduciary Duties of Pension Funds Hinder Socially Responsible Investment?" (2007) 22 BFLR 145 at 166-67; see also Gil Yaron, Fiduciary Duties, Investment Screening and Economically Targeted Investing: A Flexible Approach for Changing Times (Toronto: Shareholder Association for Research and Education, 17 May 2005) at 39, online: SHARE < http://www.share.ca/files/Fiduciary _Duties,_Investment_Screening_and_ETI.pdf $>$.

171 Alex Van der Welden and Otto Van Buul, "Really Investing for the Long Term: A Case Study" (2012) 5 Rotman Int'l J of Pension Mgmt 50.

172 In this regard, the authors respectfully disagree with the Arthurs Report, supra note 90 , which suggests at 165 that the "unequivocal mandate" of plan administrators is to "act "in the best interests of the plan" (as opposed to the beneficiaries).

173 Laby, supra note 109 at 78. 
needs without compromising the ability of future generations to meet their own needs. ${ }^{174}$

But how can we expect better, longer-term decision making processes when our legal frameworks are still largely reactive and focussed on the short term? One possibility is to strengthen the voice of beneficiaries in fund governance. ${ }^{175}$ This is already relatively commonplace in occupational pension plans. For example, the OECD Principles of Occupational Pension Regulation ${ }^{176}$ suggests that beneficiaries in defined contribution plans (in which greater financial risks are born by the beneficiaries) should be allowed to choose their investment options. ${ }^{177}$ In a similar vein, several jurisdictions require plan member (that is, nominated) representation on trustee boards in certain circumstances. ${ }^{178}$ While not "representative" in a literal sense, they can play an important role in linking plan beneficiaries to plan governance.

The idea of giving beneficiaries a voice accords with both the substance and the purposes of fiduciary law. It helps fiduciaries to fulfill their duties of loyalty and care by ensuring that they have a reasonable understanding of the interests and preferences of their beneficiaries. It can reinforce public confidence in pension administration by creating a

174 See e.g. Canadian Environmental Protection Act, 1999, SC 1999, c 33, s 3; Federal Law on Sustainable Development Act, SC 2008, c 33, s 2; Sustainable Development Act, RSQ, c D-8.1.1, s 2. This definition is based on that adopted in the 1987 Brundtland Report; see World Commission on Environment and Development, Our Common Future: Report of the World Commission on Environment and Development (Oxford: Oxford University Press, 1987) [Brundtland Report].

175 See Richardson, "Fiduciary Relationships," supra note 165 (exploring both the merits of this goal and explaining how this goal may be achieved through legislative change, including the creation of legislative duties to consult and accommodate).

176 OECD, Recommendation on Core Principles of Occupational Pension Regulation (Paris: OECD, 2004).

177 While studies have shown that individuals faced with unstructured investment choices tend to choose overly conservative investments, a plan administrator, by (1) setting default options for beneficiaries depending on their age and other relevant factors and (2) supplying a "simplified menu" highlighting a limited number of investment options that may also be appropriate for the beneficiary (while giving the beneficiary the option of requesting information on all available alternatives), can correct for this tendency. See Olivia S Mitchell and Stephen P Utkus, "How Behavioral Finance Can Inform Retirement Plan Design" (2006) 18 J Applied Corp Fin 82 at 91-93; Gur Huberman, Sheena S Iyengar and Wei Jiang, "Defined Contribution Pension Plans: Determinants of Participation and Contributions Rates" (2007) 31 J Fin Serv Res 1.

178 See e.g. Supplemental Pension Plans Act, RSQ, c R-15.1, s 147; The Pension Benefits Act, CCSM c P32, s 28.1(1.2); or Pensions Act 2004, s 241 (UK). As discussed below, providing beneficiaries a "voice" can be achieved without board representation, thereby avoiding duty of loyalty concerns. 
transparent process by which beneficiaries can learn about and help inform important decisions that affect their interests.

For beneficiaries to have a meaningful voice in fund governance, they must be (a) given sufficient information about the fund to safeguard their interests, and educated about the provisions of their plan, and (b) consulted when the trustees contemplate decisions that will affect their interests. We now turn to explore the roots of these obligations, which courts have already been recognized in a number of fiduciary contexts, and how they may apply in the context of pension administration.

\section{1) The Duty to Inform and Educate 179}

If beneficiaries are to hold trustees to standards of care and loyalty, they must know what the trust property consists of and how it is being managed. ${ }^{180}$ As one US court has noted, "Any notion of a trust without accountability is a contradiction in terms." 181 The leading US treatise Scott on Trusts has observed:

beneficiaries are entitled to know what the trust property is and how the trustee has dealt with it ... Where the trust is created in favour in successive beneficiaries, a beneficiary who has a future interest under the trust, as well as a beneficiary who is presently entitled to receive income, is entitled to such information, whether his or her interest is vested or contingent. ${ }^{182}$

Gallanis notes that such a duty to inform "should result in the beneficiaries having sufficient information to safeguard their interests ... [i.e] to monitor and evaluate the trustee's performance and, if necessary, take action in the event of a breach of trust," and, by implication, "the duty to inform should

179 In this section, we focus on the duty to inform as it applies in trust law context. As will become clear in subpart 2, where we discuss the duty to consult, the requirement that beneficiaries be given relevant information about events that affect their interests appears in the context of a number of fiduciary relationships.

180 David Hayton, "The Irreducible Core Content of Trusteeship" in AJ Oakley, ed, Trends in Contemeporary Trust Law (Oxford: Oxford University Press, 1996) 47 at 49.

181 In re Guardianship and Conservatorship of Sim, 403 N.W.2d 721, 736 (Neb. 1987); see also Schmidt v Rosewood Trust Ltd (Isle of Man), [2003] UKPC 26 at para 51 ("[the] principled and correct approach is to regard the right to seek disclosure of trust documents as one aspect of the court's inherent jurisdiction to supervise, and if necessary to intervene in, the administration of trusts").

182 Austin Wakeman Scott, The Law of Trusts (Boston: Little, Brown \& Co: 1939), $\S 173$; see also Austin Wakeman Scott and William Franklin Frachter, The Law of Trusts, 4th ed (Boston: Little, Brown \& Co: 1987), § 173; Mark L Asher and Margit P Rigney, Scott on Trusts, 5th ed (New York: Aspen Law \& Business, 2006), § 173. 
not be limited to the provision of information upon request. There must be enough information provided so that beneficiaries can make an informed request." 183 Likewise, the duty should extend as broadly as possible, to protect against the "danger of partiality." 184

In Froese v Montreal Trust Company of Canada, ${ }^{185}$ Froese (a pensioner) was not made aware of the fact that his former employer had ceased to make regular contributions to the plan, which, ultimately, resulted in the plan being wound up. He claimed against the trustee for the plan's shortfall because it had failed to warn the beneficiaries that the employer was not making regular contributions. The British Columbia Court of Appeal held that there was "an overarching obligation upon a custodial or administrative trustee to pay attention to the interests of the beneficiaries additional to its contractual duties provided in the trust indenture."186 While "this obligation is not unlimited: it arises only within the function assigned to or assumed by the trustee," it includes at minimum a duty to inform beneficiaries when their pension fund is at risk. ${ }^{187}$ This "duty to warn" of a risk of harm to the fund, the court added, was simply an aspect of the trustee's general duty of care. ${ }^{188}$ The decision attracted much commentary at the time, but has yet to be overruled. ${ }^{189}$

One means of fulfilling this duty to inform, in a way that answers the concerns regarding intergenerational equity and sustainable development highlighted at the beginning of this part, may be to embrace concepts such as the intergenerational reports which are required by law in Australia. 190

183 TP Gallanis, “The Trustee's Duty to Inform” (2007) NCL Rev 1595 at 1627. But see Tito $v$ Waddell (No 2), [1977] Ch 106, at 242 (where Megarry VC states that "trustees are under a duty to answer inquiries about the trust property ... [b]ut that is a far remove from saying that trustees have a duty to proffer information and advice to their beneficiaries; and I think the courts should be very slow to advance on the road of imposing such a duty"). Canada, along with the United States, appears to be more open to extending the duty to inform to include proactive disclosure of relevant, nonconfidential information.

184 Gallanis, ibid.

185 Supra note 88.

186 Ibid at 736.

187 Ibid at 737.

188 Ibid at 741.

189 See e.g. Hugh MB O'Reilly, “Liability of Asset Custodians and Other Fiduciaries" (1997) 14 Pension Intelligence II; Nancy B Chaplick, "Retirement Plan Disclosure Obligations: Some Hidden Issues for Financial Institutions" (2000) 19 EP \& PJ 51.

190 Charter of Budget Honesty Act 1998 (Cth), s 2(4) ("The Treasurer is to publicly release and table an intergenerational report at least once every 5 years"). For an example of such a report, see Commonwealth of Australia, Australia to 2050: Future Challenges (Canberra: Commonwealth of Australia, 2010). 
To be relevant to concerns about distributive fairness, such reports would need to focus specifically on the needs and perspectives of young people who are alive now or yet to be born. ${ }^{191}$

\section{2) The Duty to Consult}

Pension trustees across the Western world face soaring beneficiary longevity and plan deficits and, as a result, difficult choices. ${ }^{192}$ To maintain the solvency of their funds, trustees will likely need to raise premiums and cut benefits. Many plans have moved from a defined benefit system to a defined contribution or hybrid system, which transfers risk to individual contributors. ${ }^{193}$ Future generations of plan members will likely pay a disproportionate share of the costs of reform.

The Arthurs Report argues that because the risks and costs associated with these "hard choices" will be borne in large part by plan members, they should be allowed to help make these choices. ${ }^{194}$ The Report argues for greater transparency from plan administrators and more involvement by plan members in plan governance. ${ }^{195}$ This recommendation echoes calls in other jurisdictions for the recognition of a statutory "duty to consult" plan members before fiduciaries take actions that affect their interests. ${ }^{196}$

Consultation and accommodation is a critical element of perspective taking - seeing issues through the eyes of others. It may also prove a useful tool for reducing the risk that disgruntled plan members will turn to litigation, and, in turn, the risk that a court will conclude that trustees failed to consider the best interests of all of the beneficiaries and exercise care in safeguarding them. It would therefore be prudent for administrators to begin developing frameworks for consulting with beneficiaries (or their

191 For such a critique of the Australian reports see Judith C Bessant, Michael Emslie and Rob Watts, "Accounting for Future Generations: Intergenerational Equity in Australia" (2011) 70 Aust J of Pub Admin 143.

192 See e.g. "Promise Now, Bill Your Children" The Economist 403:8789 (16 June 2012), online: <http://www.economist.com/node/21556945>; Alexandre Laurin and William Robson, “Ottawa's Pension Gap: The Growing and Under-reported Cost of Federal Employee Pensions" Pension Papers (13 December 2011), online: <http://www. cdhowe.org/pdf/ebrief_127.pdf $>$; Mercer, Press Release, "US pension deficits widen for second straight year" (5 January 2012), online: Mercer <http://www.mercer.com/press -releases/US-pension-deficits-widen-for-second-year>.

193 “Over to you," The Economist 399:8728 (9 April 2011), online: <http://www. economist.com/node/18502061>.

194 Arthurs Report, supra note 90 at 53-54.

195 Ibid at $155-77$.

196 See e.g. Gary Watt, Trusts and Equity, 2d ed (New York: Oxford University Press, 2006) at 437; Richardson, "Fiduciary Relationships," supra note 165 at 631-38. 
representatives) now, rather than to wait for legislative reform and the possibility of litigation in the interim.

The concepts of consultation and accommodation are closely connected with the concept of the fiduciary relationship developed by the Supreme Court. Consultation entails informing affected groups about a proposal, soliciting information from these groups about how they would be affected by the proposal, and being prepared to modify the proposal to accommodate these groups' interests. 197

By engaging in consultation, a fiduciary may learn more about what the best interests of its beneficiaries are and how its actions will affect these beneficiaries' interests. ${ }^{198}$ It may also learn more about the social norms beneficiaries hope will guide investment decisions. With the benefit of more information, the fiduciary will likely be able to strike a balance that serves the interests of the beneficiaries as a whole (as investors and as responsible citizens) while minimizing the specific harms caused to the interests of some classes of beneficiaries. When faced with the kind of hard choices cited by the Arthurs Report, consultation can evidence the trustees' prudence and their loyalty to the best interests of the plan's beneficiaries.

Other fiduciaries that are required to balance competing interests have already been held to generally be required to consult with beneficiaries or stakeholders before taking action that might impair their interests. The Crown, for example, is generally permitted to balance Aboriginal interests against broader public interests. ${ }^{199}$ But before engaging in a balancing exercise that may harm Aboriginal rights or title, the Crown must fulfill a formal duty to consult and accommodate those Aboriginals who may be affected by its actions. ${ }^{200}$ This duty is not tantamount to a duty to agree. It

197 See Haida Nation v British Columbia (Minister of Forests), 2004 SCC 73, [2004] 3 SCR 511 at paras 16, 35, 46-47 [Haida Nation] (where the Court stated that the Crown's duty to consult with and accommodate the interests of Aboriginal peoples is "grounded in the honour of the Crown ... [and] arises when the Crown has knowledge ... of the potential existence of Aboriginal right or title and contemplates conduct that might adversely affect it"). See also Sonia Lawrence and Patrick Macklem, "From Consultation to Reconciliation: Aboriginal Rights and the Crown's Duty to Consult" (2000) 29 Can Bar Rev 252 at 264.

198 Finn, supra note 43 at 22 ("If the fiduciary is to act in his beneficiaries' interests $\ldots$ in some cases he may only be able to exercise his discretion properly by obtaining information from them. Likewise he should, where appropriate, explain his own views to them").

199 Wewaykum Indian Band v Canada, 2002 SCC 79, [2002] 4 SCR 245 at para 96.

200 Haida Nation, supra note 197 at paras 18, 21-38. In West Moberly First Nations v British Columbia (Chief Inspector of Mines), 2011 BCCA 247, [2011] 3 CNLR 343, leave to appeal to SCC refused, [2011] SCCA No 399 (QL), the BC Court of Appeal 
does not extend a veto to First Nations over government action. Rather, it requires that both sides negotiate in good faith and that the Crown take reasonable steps to accommodate Aboriginal interests. ${ }^{201}$

While consultation is simpler when undertaken with cohesive groups who enjoy established structures of representation, it is increasingly being extended to groups with little or no such cohesion. For example, corporate directors, in exercising their business judgment as to the best interests of the corporation, are permitted to balance the interests of various stakeholders and make decisions that help some stakeholders while harming others. But before reaching these decisions, they are obliged to consider the position of the affected stakeholders. ${ }^{202}$ While there is not a formal duty to consult, exercising business judgment in practice increasingly entails consulting with stakeholders. For instance, in $B C E$, the board was held to have met this requirement by receiving submissions from stakeholders and meeting with them or their representatives. ${ }^{203}$

The concept of consultation is familiar to pension law. As noted, there is case law that indicates that pension plan trustees must look to the interests of different classes of plan members before making decisions that affect their interests. ${ }^{204}$ In addition, Ontario pension legislation requires administrators to consult with beneficiaries before applying to amend a pension plan in a way "that would ... adversely affect the rights or obligations of a ... person entitled to payment from the pension fund." 205 Federal pension legislation, along with pension legislation in Ontario, British Columbia, and Nova Scotia, also allow current and former members of a plan to establish an advisory committee to monitor and make recommendations regarding the administration of the plan. ${ }^{206}$ The federal legislation provides that, where the administrator is a pension committee,

adopted a broad interpretation of the duty to consult, holding that it must include consideration of "cumulative effects" of "past wrongs" and the impact of future developments extending beyond the immediate consequences of the mining exploration permits that were in issue. The duty to consult also extends beyond situations where the Crown is under a fiduciary obligation, applying in any situation where "the honour of the Crown" is engaged; see Haida Nation, ibid.

201 Ibid.

202 BCE, supra note 104 at paras 101-102. See also Peoples, supra note 140 at paras 41-42.

203 BCE, ibid at paras 103-104.

204 See e.g. supra notes 126-132.

205 OPBA, supra note 96, s 26(1).

206 Ibid, s 24; BCPBA, supra note 96, s 69; NSPBA, supra note 96, s 30A; CPBSA, supra note 89 , s 7.2 . 
plan members may be represented on that committee if a majority of them so request. 207

Applying a duty to consult in this manner would help to give existing beneficiaries a voice in pension plan decision making. The more challenging question, however, is how to provide a voice for contingent beneficiaries. Brown Weiss has suggested giving standing to representatives of future generations in technical and administrative proceedings or appointing a public office charged with "ensuring that positive laws conserving our resources are observed."208 Sunstein's principle of intergenerational neutrality (that "the decade of one's birth has no moral relevance any more than does one's skin colour or sex") 209 may be a helpful norm for such surrogates to advocate and monitor, as could the Great Law of the Iroquois, which requires that decisions be made with regard for the impact on the next seven generations. ${ }^{210}$

Here, again, existing legal instruments in trust law may be instructive and helpful. The use of a "trust advisor," typically to work with the trust's asset managers in reviewing their decisions, and the logic associated with them, dates back a century. ${ }^{211} \mathrm{~A}$ more recent phenomenon is the advent of trust protectors. ${ }^{212}$ This instrument gained popularity for investors who seek to use offshore trusts but are reluctant to cede full control of their assets to a foreign trustee. To address this problem, legislation in various offshore jurisdictions legitimated the concept of a domestic "trust protector,"

207 CPBSA, ibid, s 7.1.

208 Edith Brown Weiss, In Fairness to Future Generations: International Law, Common Patrimony, and Intergenerational Equity (Dobbs Ferry, NY: Transnational Publishers, 1989) at 120.

209 Cass Sunstein, Worst Case Scenarios (Cambridge, Mass: Harvard University Press, 2007) at 269.

210 Linda Clarkson, Vern Morissett and Gabriel Régallet, Our Responsibility to the Seventh Generation (Winnipeg: International Institute for Sustainable Development, 1992), online: www.iisd.org/pdf/seventh_gen.pdf.

211 See e.g. In re Rogers (1928), 63 OLR 180. The trust litigated in In re Rogers provided that the "executors and trustees shall be governed by the advice of one who is neither a beneficiary nor a trustee or executor himself;" see ibid at 182 . The advisor in that case, conflicted by a personal interest, purported to veto the trustee's sale of shares. The Court, affirming that a trust advisor's role is inherently limited, allowed the sale of the shares without the advisor's consent. It found that to do otherwise would "place [the advisor] in the...position of a sort of super-trustee who is neither responsible to the trustees or the beneficiaries nor subject to the control or discretion of the Court;" see ibid at 183 .

212 See e.g. Stewart Sterk, "Trust Protectors, Agency Costs and Fiduciary Duty" (2006) 27 Cardozo L Rev 2761; Philip J Ruce, "The Trustee and the Trust Protector: A Question of Fiduciary Power. Should a Trust Protector be Held to a Fiduciary Standard?"(2010) 59 Drake L Rev 67. 
who can have limited powers over the trustee, as well as the trust itself, without defeating the original purpose of the offshore trust (by giving control over the trust assets to the settlor or beneficiary). ${ }^{213}$

Given the dynamic nature of social norms and in the absence of clear jurisprudence as to the meaning of "reasonable expectations," 214 one might expect fiduciaries to consult with stakeholders as a matter of course. Allowing plan members to play a role in the decision-making process increases the likelihood that they will see the decision reached by the trustees as fair. It reduces trustees' legal risk by providing strong evidence that the trustees made their decision in accordance with their duties of loyalty and care. Retaining a trust advisor or trust protector to represent future generations of beneficiaries may lend further legitimacy to trustees' decisions.

\section{3) The Duty to be Strategic}

One of the unintended consequences of the intense regulatory focus on risk management and compliance has been to distract attention from the (complementary) need for strategy management and oversight. In the corporate context, a recent McKinsey survey of over 2,000 executives about a set of 10 basic strategic tests found that only $35 \%$ of their firms' strategies satisfied more than three of them. ${ }^{215}$ In the uncertain times we live in, ensuring that organizations achieve their purpose (in the case of pension plans, to satisfy their obligations to beneficiaries) requires leaders

213 See Jan Dash and Herman Liburd, "The Role of Protectors in Offshore Trusts" (2003) 1 Trust Q Rev 19.

214 One source of "reasonable expectations" may prove to be soft law; see Ryan Goodman and Derek Jinks, "How to Influence States: Socialization and International Human Rights Law" (2004) 51 Duke LJ 621 at 638-56 (discussing how "acculturation" through the development of norms can influence state actors). Soft law also has a tendency to develop into binding treaty law later on; see e.g. Geoffrey Palmer, "New Ways to Make Environmental Law" (1992) Am J Int'l L 259 at 269 ("soft law ... is particularly helpful in creating a climate that can produce a hard law instrument"); Kal Raustiala, "Transgovernmental Networks and the Future of International Law" (2002) 43 Va J Int'l L 1 at 86 ("[s]oft law is often seen as a stepping stone to hard (treaty) law"). See also UNESCO, Declaration on the Responsibilities of the Present Generations Towards Future Generations, GC Res 44, UNESCOOR, 29th Sess, UNESCO Doc 29 C/Res 44 (12 November 1997).

215 See Chris Bradley, Martin Hirt and Sven Smit, "Have You Tested Your Strategy Lately?" McKinsey Quarterly (January 2011) 40, online: McKinsey Quarterly $<$ http://www.mckinseyquarterly.com/Have_you_tested_your_strategy_lately_2711>; Chris Bradley, Lowell Bryan and Sven Smit, "Managing the Strategy Journey" McKinsey Quarterly (July 2012) 50, online: McKinsey Quarterly <http://www.mckinseyquarterly .com/Managing_the_strategy_journey_2991>. 
to give as much attention to developing and executing strategies as to risk management and operational issues. The challenge may be to refocus legal norms on managing strategy, as well as risk. One commentator has gone so far as to recommend clarifying the fiduciary duties of corporate directors specifically to reflect this role and responsibility. 216

A focus on strategy imposes an additional and necessary discipline on trustees insofar as it defines a mission and processes for long-term value creation that informs trustee conduct. Fund management and oversight is clearly about more than limiting losses. While policy-makers typically think of "risk" in its down-side sense, it is difficult, conceptually, to separate it from the management of strategy. Both require the engagement of senior management and the trustees on an ongoing basis to ensure that there are rigorous and effective processes in place.

Institutional capacity to understand, plan for, and adapt to change requires strong leaders with the capacity for strategic thinking. It requires leaders who can contextualize and manage expectations as to what may be achieved and in what time frame. In times of stress, it's human nature to adopt a narrow, short-term focus. Under-investment by fund fiduciaries in broader, longer-term analytic capacity (for example, to think about the collective macro impacts of their fund's micro investment decisions) is analagous to under-investment in physical infrastructure. In both cases, the consequences are not immediate, but in the long run, they diminish institutional and systemic resilience, transfer costs to a future cohort, and create cascades of collateral damage when there is a failure. ${ }^{217}$

\section{Conclusion: The Pressing Duty to Collaborate}

In recounting the Supreme Court's extended effort to develop a broader conceptual framework for fiduciary duties and exploring how that framework might be applied to the challenges faced by pension trustees, we have tried to identify various emerging and potential obligations (and consequential liabilities) as well as steps that might be taken to address them. While our focus has been on how best to respond to obligations flowing from the duties of loyalty and impartiality," there remains a

216 Nadelle Grossman, “The Duty to Think Strategically” LA L Rev (forthcoming in 2013) online: SSRN < http://ssrn.com/abstract=1919145> (linking this duty to the duty of good faith held to exist in Caremark and Stone $v$ Ritter).

217 See e.g. Roger L Martin, "The Gaming of Games" Drucker Society Europe Blog (17 October 2012), online: Drucker Society Europe Blog http://www. druckerforum.org/blog/? $\mathrm{p}=190$. Martin argues that while stock lending by pension funds increased annual returns, it will immeasurably reduce long-term returns. 
broader and pressing duty of care challenge that is of immediate relevance to pension trustees.

Very few crises respect institutional mandates or jurisdictions. A classic immune system response is swarming - blood clotting when we cut ourselves and white blood cells fighting an infection. This type of selforganization, the ability to marshal an "all hands on deck" reaction, is critical to building resilient institutions. Achieving this level of intelligence and "response-ability" requires extensive networks, within and across organizations, which have to be built up over time, invested in and nurtured. ${ }^{218}$

In his book Nonzero, ${ }^{219}$ Wright argues that as societies become more complex, we are driven, in pursuing our self-interest, to cooperate and find nonzero-sum solutions to social problems - solutions that produce benefits for third parties as well as ourselves. This is the logic underlying the Court's promotion of the "fiduciary society" concept and similar developments in other jurisdictions. ${ }^{220}$

The notion is not new; it emerges from game theory. ${ }^{221}$ Nor has its logic escaped those responsible for international financial stability. Consider, for example, the Financial Stability Board (which evolved from the Financial Stability Forum).222 It represents part of a continuing effort to improve collaborative oversight of systemically significant financial intermediaries by embracing a new approach to prudential supervision and crisis management. 223 Similar efforts to develop better structures and practices of collaborative crisis management are now playing out within and beyond the European Union. Over time, such efforts, in and of themselves, give rise to reasonable expectations (for example, the expectation that strategies of collaboration will be deployed with increasing reliability to stabilize markets) that in turn inform legal norms.

The obstacles to collaboration have been the subject of academic research since the publication almost fifty years ago of The Logic of

218 Kevin Lynch and Ed Waitzer, "Building resilience in an age of crisis" Globe and Mail (17 January 2011) B2.

219 Robert Wright, Nonzero: The Logic of Human Destiny (New York: Vintage Books, 2001).

220 See Frankel, "Fiduciary Law," supra note 44; Rotman, supra note 31 (on how this framework likely also drives the development of fiduciary law in the United States).

221 See e.g. Axelrod, supra note 48; Rapoport, supra note 48.

222 G20, Declaration on Strengthening the Financial System (2 April 2009).

223 Louis W Pauly, "The Old and the New Politics of International Financial Stability" (2009) 47 J of Common Market Studies 955. 
Collective Action, 224 in which Mancur Olson challenged the "democratic" notion that groups would form and take collective action when doing so would serve their common interests. Instead, he asserted that, absent coercion or direction, "rational, self-interested individuals will not act to achieve their common or group interests" 225 (this assertion is referred to as the "zero contribution thesis"). However, as Wright observes, selforganized governance regimes are not only possible but, increasingly, imperative. There is a wealth of empirical research that identifies contextual variables that support and reinforce collaborative responses to social problems. ${ }^{226}$

The opportunity for pension trustees (and other institutional investors) to have an effect when acting collectively, both amongst themselves and with asset providers, is great, as is the opportunity cost of defaulting (or feigning collective action with no resolve to execute on the "talk").227 This reflects the dominant (and still-growing) level of institutional ownership as well as the challenges of retirement income provision. The scale of such investment pools and the demands on them will certainly attract increasing expectations and scrutiny.

The challenges to effective institutional collaboration by fund trustees (and other institutional investors) with respect to governance rights - both at the level of an individual corporation and systemically, are at least twofold. First, existing business models (including metrics and compensation) reward expertise in managing portfolios (as opposed to investing in and engaging with companies), measured comparatively over the short term. These models reward actors that deliver competitively superior short-term performance while minimizing short-term costs and punish actors that make governance investments that do not pay off in the short term. Second, to the extent governance interventions are unlikely to have a strong effect on portfolio returns and may impair relative performance (especially where others can free ride or the fund needs to deviate from a passive index in order to overweight its investment in the target company), the logic of diversification further cuts against investment in governance rights. ${ }^{228}$

224 (Cambridge, Mass: Harvard University Press, 1965).

225 Ibid at 2.

226 See e.g. Elinor Ostrom, "Collective Action and the Evolution of Social Norms" (2000) $14 \mathrm{~J}$ of Econ Perspectives 137; Elinor Ostrom, "A diagnostic approach for going beyond panaceas" (2007) 104 Proc Nat'l Acad Sci USA 15181.

227 See Ed Waitzer, "Defeating Short-Termism: Why Pension Funds Must Lead" (2009) 2:3 Rotman Int'l J of Pension Mgmt 4.

228 See Marcel Kahan and Edward B Rock, "Hedge Funds in Corporate Governance and Corporate Control” (2007) 155 U Pa L Rev 1021. 
Given institutional investors' competency and incentive deficits with regard to governance, it is not surprising that their governance rights are undervalued. As Gilson and Gordon note, such investors are "not so much rationally passive as rationally reticent," waiting for other actors to identify problems and propose solutions that serve the interests of investors' beneficiaries. ${ }^{229}$ They note the emergence of shareholder activists that seek to fill this role, characterizing such activists as "governance entrepreneurs" - framing and seeking to force governance changes but ultimately dependent upon attracting broad support from institutional investors (and thereby giving such institutions indirect governance capacities). ${ }^{230}$

There remains considerable distance between academic and regulatory ideals and the present reality. Institutions remain "stubbornly responsive but not proactive." 231 While shareholder activists clearly fill a gap in governance markets, they may also exacerbate the myopic consequences of existing institutional competencies and incentives where these activists' goals are oriented towards the short-term. ${ }^{232}$ They may also help to mask the underlying problem by suggesting that institutions can and will play a more proactive role in corporate governance. The general acceptance of principles of responsible investment, active ownership and similar initiatives can easily become a facade to hide behind. Gilson and Gordon refer to this challenge as the "possibility that the institutions will, like Pinocchio, come to act like real boys - like real owners and actively supervise the performance of professional management."233

Similar hazards arise from the growing subscription (but not necessarily meaningful commitment or adherence) by institutional investors to "best practice" standards - too often giving rise to an appearance of stewardship by "ticking boxes" with respect to the features (rather than the functions) of good governance and stewardship. An additional risk is that such standards often presume, incorrectly, "a unique

229 Ronald J Gilson and Jeffrey N Gordon, "The Agency Costs of Agency Capitalism: Activist Investors and the Revaluation of Governance Rights" Colum L Rev (forthcoming in 2013) at 48, online: SSRN <http://papers.ssrn.cin/sol3/papers.cfm ?abstract id=2206391.>.

230 Ibid at 31. See also Edward B Rock, "The Logic and (Uncertain) Significance of Institutional Shareholder Activism" (1991) 79 Geo LJ 445 at 479-81.

231 Gilson and Gordon, supra note 229 at 22.

232 See e.g. Martin Lipton, Steven A Rosenblum and Karessa L Cain, "Some Thoughts for Directors in 2012" (7 December 2011) at 2-3, online: Wachtell, Lipton, Rosen \& Katz <http://www.wlrk.com/files/2012/SomeThoughtsforBoardsofDirectorsin 2012.pdf $>$.

233 Gilson and Gordon, supra note 229 at 23. See also Marcel Kahan and Edward B Rock, "Hedge Funds in Corporate Governance and Corporate Control" (2007) 155 U Pa L Rev 1021 at 1047, 1091-92. 
set of appropriate institutional arrangements ex ante, and view convergence toward those arrangements as inherently desirable." 234 Worse yet, such standards tend to be backward-looking - based on and reacting to past failures, rather than anticipating where markets will be going. This invites gaming, similarly reactive (and often politically-driven) regulation, and the ossification of governance processes. ${ }^{235}$ The medical equivalent would be to treat only acute symptoms, rather than taking a holistic view of the patient. In engineering terms, the equivalent would be to fix defective parts each time there is a failure rather than ensure quality and integrity from the outset. The costs of such reactive governance - both in tangible terms and in terms of public trust - are immense.

A similar dynamic is at play with respect to competing time horizon equilibria. In the first, patience wins the day, where the proportion of longterm investors increases and "the self-correcting tendencies of market prices are thus reinforced, further supporting long-term investors." 236 The other operates in reverse gear: the proportion of short-term traders grows and the very meaning of "short-term" compresses, increasing the degree of misalignment in prices. ${ }^{237}$ Haldane has argued that, for a variety of reasons, financial markets have succumbed to a self-destructive cycle of impatience.

This challenge was illustrated in a recent Wall Street Journal article about a training simulation run by Brandes Investment Partners LP for pension plan trustees, in which teams of about five trustees are competing to produce the best returns. While, given the nature and duration of pension fund obligations, trustees should be focusing on results over longer periods, the article notes that the participants tended to focus on short-term results: "[I]t's hard to resist a manager on a hot streak-and it's tempting to dump a long-term winner in a slump."238

234 Dani Rodrik, "Second-Best Institutions" (2008) 98 Am Econ Rev 100 at 100.

235 Andrew G Haldane and Vasileios Madouros, "The Dog and the Frisbee" (Address given at the Federal Reserve Bank of Kansas City's 366th economic policy symposium, "The changing policy landscape," Jackson Hole, Wyoming, 31 August 2012) at 6-8, online: Bank for International Settlements $<$ http://www.bis.org/review/r120905a .pdf $>$

236 Andrew G Haldane, "Patience and Finance" (Address given at the Oxford China Business Forum, Beijing, 2 September 2010) at 11, online: Bank of England $<$ http://www.bankofengland.co.uk/publications/Documents/speeches/2010/speech445 .pdf $>$.

237 Ibid.

238 Karen Damato and Veronica Dagher, "Game Changer: Play Money Teaches Real Lessons on Managing Investments" Wall Street Journal (4 June 2012) C5, online: Wall Street Journal <http://online.wsj.com/article/SB1000142405270230420360457739 4431579048676.html>. 
Recall our initial assertion that the "Canadian model" of pension management and delivery "punches above its weight." This was based on the size of major Canadian public pension plans and the fact that considerable effort has been invested in best practices in internal governance and investment management. Many other jurisdictions are embracing these concepts in designing their retirement income institutions.

In such a framework, it should be both simpler and imperative to move beyond a focus on portfolio-level benefits to a consideration of systemic effects. As Lydenberg and others have argued, the narrow focus on outperforming (or, more precisely, not underperforming) market benchmarks that emerged as a rational "fiduciary" response to modern portfolio theory is based on zero-sum logic. ${ }^{239}$ It seeks merely to beat the market today, without considering how investment can be used to expand and improve the market tomorrow.

Ironically, as financial assets have been aggregated and financial decisions scaled up, the portfolio-level focus on investment has tended to both give rise to and ignore systemic risks. For example, it was such behaviour that contributed to the proliferation of risky products (driven by investors' increased appetite for risks and return). By ignoring the relationship between portfolio investment and market-level returns, modern portfolio theory also increased the role of speculators (and high frequency traders) and narrowed the temporal focus of markets. As previously discussed, "herd behaviour" has tended to amplify rather than help control risks.

Given the lessons learned, as well as the systemic significance and impact of institutional investors as "universal owners," 240 it is intuitively compelling that pension fiduciaries should be focusing on ways in which their investments can benefit the whole and, in so doing, mitigate risk and increase return. This means taking into consideration how their investment decisions will affect the stability of financial systems, the direction of the economy and the sustainability of our environment.

239 See e.g. Steve Lydenberg, "Beyond Risk: Notes Toward a Responsible Investment Theory" in James Hawley, Shyam Kamath amd Andrew Williams, eds, Corporate Governance Failures: The Role of Institutional Investors in the Global Financial Crisis (Philadelphia: University of Pennsylvania Press, 2011) 26; see also Peter L Bernstein, Capital Ideas: The Improbable Origins of Modern Wall Street (New York: John Wiley \& Sons, 2005) at 120-121.

240 James P Hawley and Andrew T Williams, The Rise of Fiduciary Capitalism: How Institutional Investors can make Corporate America more Democratic (Pittsburgh: University of Pennsylvania Press, 2000). 
Put differently, the fact that an investment decision may result in positive relative financial returns over the short-term (in which performance management is typically measured) has no bearing on whether such an investment will yield benefits to current or future pension beneficiaries. Such decisions (and hence the duty of care) must take into account the relationship between investment decisions and systems in which the beneficiaries (will) live. ${ }^{241}$

The California Public Employees' Retirement System (CalPERS) addresses these issues in its recent sustainable investment report. ${ }^{242}$ The report highlights the need to work in partnership with others to build consensus and promote ESG goals that contribute to sustainable risk adjusted investment returns. ${ }^{243}$ CalPERS has also adopted a set of principles of accountability and transparency for their own governance. ${ }^{244}$

Current imbalances in our economy, if unaddressed, are likely to exacerbate a range of health, educational and social problems in what could easily give rise to a vicious cycle. ${ }^{245}$ Ultimately, investing is a means for pension fund trustees to ensure the future well-being of beneficiaries. Financial returns are a necessary element but, in considering the interests of beneficiaries, so, too, are other concerns. It is in this context that pension trustees become "public" fiduciaries. Given the mission, size, and systemic significance of pension funds, this suggests a "duty to collaborate" (and consequential behavioural shifts). This goes beyond seeking cost advantages to the heart of effecting systemic reform.

241 See e.g. Lydenberg, supra note 25.

242 CalPERS, "Towards Sustainable Investment - Taking Responsibility" (October 2012), online: <http://www.calpers.ca.gov/index.jsp?bc=/about/press/news /invest-corp/towards-sustainable-investment.xml>.

243 Ibid.

244 CalPERS states that these principles reflect each Board member's commitment to: (a) being effective and capable fiduciaries; (b) being ethical leaders; (c) being open and accountable to our stakeholders; (d) being risk intelligent and insightful in decisions; (e) taking a long-term view of the needs of beneficiaries and system participants; and (f) undertaking continuous learning and adaptation to changing conditions. For detailed descriptions of each principle see, online: http://www.calpers.ca.gov/eip-docs/about /organization/board/02152012-board-governance.pdf.

245 See e.g. James Manyika et al, "An Economy that Works: Job Creation and America's Future" McKinsey Global Institute (June 2011), online: McKinsey \& Company $<$ http://www.mckinsey.com/insights/mgi/research/labor_markets/an_economy _that_works_for_us_job_creation $>$ (which discounts the possibility of a recovery to "full employment," i.e., 5 percent unemployment, in the United States before 2020 and documents the mismatch of predicted opportunities with available skills and education levels). 
A recent Harvard Business Review blog analogized to the beginnings of the US space program, where a perceived crisis (losing the US's scientific edge to the Soviet Union) led leaders to think and collaborate across sectors based on timescales that would outlive their leadership and in ways that would inspire new generations. ${ }^{246}$ Forming networks of thought, communication and collective action has become a fiduciary imperative in addressing today's critical challenges. Early efforts to do so have been characterized by solemn declarations and aspirational standards - a necessary but insufficient starting point. There is increasing urgency to impose accountability for action on such networks - developing and operationalizing standards that will better enable the pension fund community to fulfill its obligations to beneficiaries (and a corresponding commitment by the fund trustees). If not addressed proactively, the likelihood of incremental, reactive regulation and of disruptive liability awards (and other costs) is high. ${ }^{247}$ These are the suboptimal defaults.

There remains much to learn about the possibilities of success, failure and reinvention. That process must be addressed through collective action that can stand the test of time. Current efforts to do so should be renewed and supported.

246 Eric Lowitt, "What the Space Race Can Teach Us About Collaboration" HBR Blog Network (17 October 2012), online: HBR Blog Network <http://blogs .hbr.org/cs/2012/10/what_the_space_race_can_teach_us_about_collaboration.html $>$.

247 See e.g. Planning and Compulsory Purchase Act 2004 (UK), c 5, s 33A(1); Localism Act 2011 (UK), c 20, s 110(1) (which imposes a "duty to cooperate" on various national and local authorities to "engage constructively, actively and on an ongoing basis" to develop strategic policies and requires local councils to consider joint approaches to plan making). 